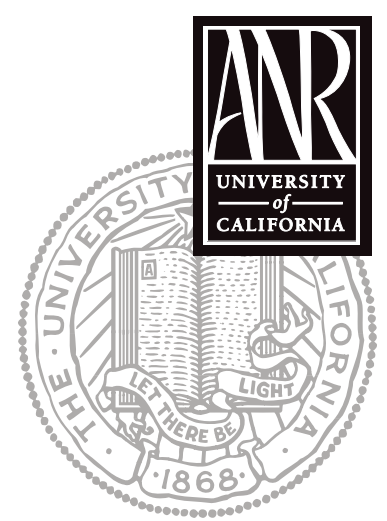

UNIVERSITY OF CALIFORNIA

Division of Agriculture and Natural Resources http://anrcatalog.ucdavis.edu

\title{
Dryland Pastures: Establishment and Management in the Intermountain Region of Northern California
}

ROB WILSON, UC Cooperative Extension Farm Advisor, Lassen, County; DAVID LILE, UCCE Farm Advisor, Lassen County; DAN DRAKE, UCCE Farm Advisor, Siskiyou County; STEVE ORLOFF, UCCE Farm Advisor, Siskiyou County; DON LANCASTER, UCCE Farm Advisor, Modoc County; HOLLY GEORGE, UCCE Farm Advisor, Plumas-Sierra Counties; RICK DELMAS, UCCE Farm Advisor, Inyo-Mono Counties; and ALAN BOWER, USDA Natural Resources Conservation Service Range Specialist, Plumas-Sierra Counties

\section{PREFACE}

This publication is the outcome of teamwork among University of California Cooperative Extension (UCCE) personnel to provide information to help land managers establish and improve pasture in the intermountain region of Northern California. Lassen, Modoc, Siskiyou, eastern Shasta, Plumas, Sierra, Inyo, and Mono Counties make up this area (Figure 1). Separately authored sections address management practices specific to California's intermountain climate and land use, and much of the content is based on UCCE research within Northern California. The sections are organized to provide step-by-step guidance through the basic principles of pasture establishment, maintenance, and improvement. At the end of the publication you will find a list of additional resources that you can use to pursue further investigation and understanding of specific topics.

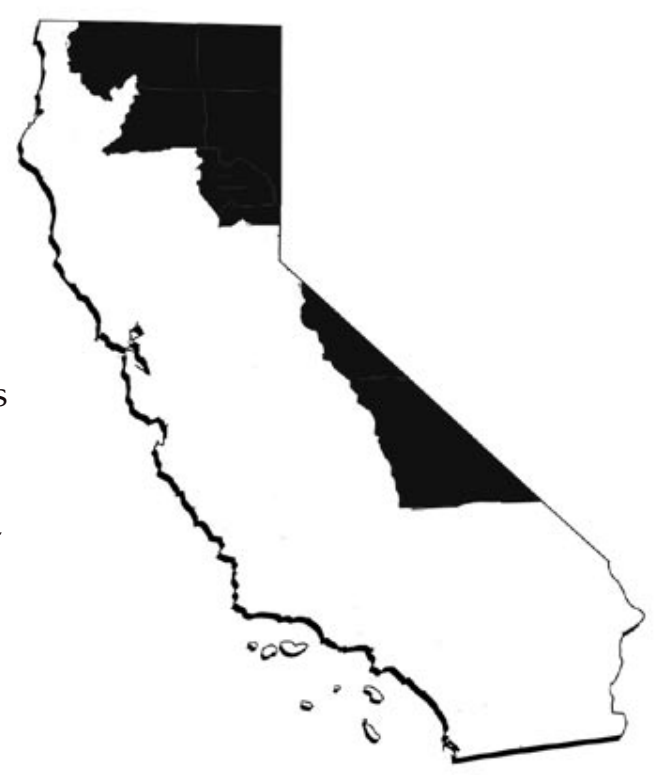

Figure 1. The intermountain region of California (shaded area).

\section{CONTENTS}

Introduction $\bullet$ Holly George and Dan Drake . . . . . . . . . . . . . . . 2

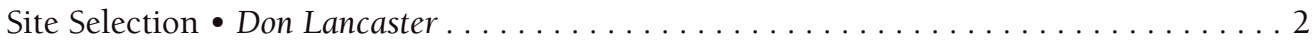

Plant Species Selection • David Lile, Dan Drake, Don Lancaster, and Rick Delmas . . . . . . 3

Site Preparation and Planting Methods • Steve Orloff and Rick Delmas . . . . . . . . . . . 9

Weed Control • Rob Wilson and Steve Orloff . . . . . . . . . . . . . . . . 13

Fertilization $\bullet$ Don Lancaster and Rob Wilson . . . . . . . . . . . . . . . . 17

Management After Planting • Dan Drake and David Lile . . . . . . . . . . . . 18

Additional Technical and Financial Assistance • Holly George and Alan Bower . . . . . . . 21

Useful Resources . . . . . . . . . . . . . . . . . . . . . . 23

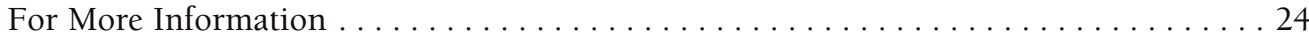




\title{
INTRODUCTION
}

\author{
Holly George and Dan Drake
}

Dryland pasture is an important component of Northeast California agriculture. When it is managed well, pasture provides valuable livestock forage and offers several indirect benefits including wildlife habitat, erosion control, weed prevention, and aesthetic value. Most pastures are composed of native and/or introduced plant species maintained for the primary purpose of livestock grazing. Dryland pasture production levels are strongly influenced by forage species, climate, and management.

Northeast California's climate zones vary from high mountain desert to alpine forest. An aerial view shows forest-covered mountains with valleys interspersed. Land elevations range from 2000 to over 6500 feet and areas are subject to extremes in temperature and precipitation. Annual precipitation levels vary from less than 10 inches on many eastern slopes and other localized areas to more than 80 inches in some western portions of the region. Some of the precipitation comes in the form of snowfall, which can be heavy at higher elevations. The length and dates of the growing season vary. In some areas, a seven-month growing season is common, while in other areas a killing frost may occur at any time of year. Due to these widely varying conditions, intermountain pastures are unique from location to location and require specific management that is closely coordinated with local site characteristics.

The sections that follow address most aspects of establishment and subsequent management of dryland pasture in the intermountain region. The publication covers important considerations for site selection and plant species choice, examples of seed mixes that are appropriate for different climates and land-use plans, seeding rates, seed-bed preparation methods, planting times (spring vs. fall), seeding methods (drill, broadcast, no-till drill, etc.), weed control, fertilization, and grazing management.

\section{SITE SELECTION}

\section{Don Lancaster}

When assessing a location's potential for dryland pasture production, you should always consider the following site characteristics:

Adequate annual precipitation. On most dryland sites in the intermountain region, available soil moisture is the limiting factor for plant growth and establishment. Most dryland forage species require at least 12 inches of annual precipitation for adequate growth and long-term survival. Sites with less precipitation have limited productivity and may not provide an adequate economic return.

Adequate soil depth. To provide sufficient water-holding capacity for productive plant growth, the soil depth must be at least 18 inches. While shallower soils can be planted, they seldom provide enough production for sustainable economically viable yields.

Appropriate soil texture for root development and growth. Soil texture and depth determine a soil's water-holding capacity and therefore strongly influence a site's potential for forage production. Soil textures ranging from a sandy loam to silt or clay loam are most suitable for forage plant growth. Sandy soils lack sufficient water-holding capacity to sustain production through dry periods of the growing season.

Adequate drainage to prevent waterlogging. Most dryland grass species thrive in well-drained soils that have no shallow subsurface restrictive layers. Two common types of restrictive layer are clay lenses and volcanic ash layers. If restrictive layers exist at a site, determine their depth and the feasibility of sub-soiling (ripping) them with a 
tillage implement before planting. In most cases, it is not cost-effective to sub-soil subsurface layers over a large area for dryland pasture.

Freedom from excess salt accumulation (especially sodium). Salt-affected soils present several problems for dryland pasture establishment. The accumulation of salt in soils has a negative influence on several soil properties, including soil structure, water infiltration, and nutrient availability. High salt concentrations also inhibit plant growth and seedling establishment. If you suspect that a salt problem exists, conduct a soil salinity test to determine the extent of the problem and then consider planting grass species that are tolerant to current salinity levels. Reclamation of salt-affected soils is rarely cost-effective for dryland pasture.

Freedom from rocks. The presence of large rocks in the soil rules out most cultivation and planting options and significantly reduces the potential for success in establishing a dryland pasture. For this reason, avoid rocky areas whenever possible.

Slope. Generally speaking, slopes should be less than 15 percent in order to accommodate planting and soil preparation equipment and minimize the potential for erosion. Given a choice, most classes of livestock prefer to graze on slopes of less than 30 percent.

Freedom from overstory vegetation. Before you establish a new pasture, it is important that you reduce competition from large woody species such as juniper trees and sagebrush. Dense overstory vegetation should be removed or thinned both to decrease competition for moisture and light and to reduce the potential for soil erosion. Overstory removal will aid in seedling establishment. See the Weed Control section for information on dealing with shrubs and juniper.

\section{PLANT SPECIES SELECTION}

\section{David Lile, Dan Drake, Don Lancaster, and Rick Delmas}

\section{Considerations for Species Selection}

Selecting appropriate plant species is one of the most important and fundamental steps in establishing dryland pasture. While there is quite an array of available dryland species, you can usually narrow the choice down to just a few by applying the criteria listed below. The three main criteria that you should always consider when selecting dryland pasture species are land-use objectives and future management plans of the pasture, soil and climatic characteristics of the site, and availability and cost of seed.

\section{Land-Use Objectives and Future Management Plans for the Pasture}

It is important to choose plant species that are capable of meeting your specific landuse objectives for the pasture. Many land managers have multiple objectives for a dryland seeding, which may include increasing livestock forage, controlling erosion, reducing weed infestations, providing wildlife habitat, restoring the native plant community, or some combination of these. If livestock forage production is the most important objective, look for forage species that respond well to grazing and are productive and palatable to livestock (Table 1). If weed suppression is a concern, consider species with good seedling vigor, high yield potential, and tolerance to herbicides that are commonly used on the site. Plants to consider include grasses, forbs, and shrubs (Table 2). Grasses constitute the main component of most dryland seedings because they are easy to establish, provide effective erosion control, and supply nutritious forage for livestock. Forbs such as clovers and alfalfa are also included in many dryland seedings. Usually forbs and shrubs are seeded as a small component of the total plant community, but they may provide important contributions including species diversity, high-quality forage, and sustained growth at different times of the year. 
Table 1. Forage values of selected dryland species ( $\mathrm{L}=$ low, $\mathrm{M}=$ medium, $\mathrm{H}=$ high)

\begin{tabular}{|c|c|c|c|}
\hline $\begin{array}{l}\text { Forage plant } \\
\text { (recommended varieties/selections } \\
\text { in italics) }\end{array}$ & $\begin{array}{l}\text { Yield } \\
\text { potential* }\end{array}$ & $\begin{array}{l}\text { Grazing } \\
\text { tolerance }\end{array}$ & Palatability \\
\hline \multicolumn{4}{|l|}{ Grasses } \\
\hline $\begin{array}{l}\text { Bluegrass, Big } \\
\text { Sherman }\end{array}$ & $\mathrm{H}$ & M & $\mathrm{H}$ \\
\hline Bluegrass, Canby Canbar & $\mathrm{L}-\mathrm{M}$ & M & $\mathrm{H}$ \\
\hline Bluegrass, Sandberg & $\mathrm{L}$ & M & $\mathrm{H}$ \\
\hline $\begin{array}{l}\text { Brome, Meadow } \\
\text { Fleet, Paddock, Regar }\end{array}$ & $\mathrm{M}-\mathrm{H}$ & $\mathrm{M}-\mathrm{H}$ & $\mathrm{H}$ \\
\hline $\begin{array}{l}\text { Brome, Mountain } \\
\text { Bromar (short-lived) }\end{array}$ & $\mathrm{M}-\mathrm{H}$ & M & $\mathrm{M}-\mathrm{H}$ \\
\hline $\begin{array}{l}\text { Brome, Smooth } \\
\text { Lincoln, Manchar }\end{array}$ & $\mathrm{M}-\mathrm{H}$ & M & $\mathrm{M}-\mathrm{H}$ \\
\hline $\begin{array}{l}\text { Fescue, Idaho } \\
\text { Joseph }\end{array}$ & M & M & $\mathrm{M}-\mathrm{H}$ \\
\hline $\begin{array}{l}\text { Foxtail, Creeping meadow } \\
\text { Garrison }\end{array}$ & M & $\mathrm{H}$ & $\mathrm{M}-\mathrm{H}$ \\
\hline Needlegrass, Columbia & $\mathrm{M}$ & $\mathrm{L}-\mathrm{M}$ & M \\
\hline Needlegrass, Needle and thread & M & L-M & M \\
\hline $\begin{array}{l}\text { Orchardgrass } \\
\text { Paiute }\end{array}$ & $\mathrm{M}-\mathrm{H}$ & $\mathrm{M}-\mathrm{H}$ & $\mathrm{H}$ \\
\hline $\begin{array}{l}\text { Squirreltail, Bottlebrush } \\
\text { Sand Hollow }\end{array}$ & M & $\mathrm{M}-\mathrm{H}$ & M \\
\hline $\begin{array}{l}\text { Wheatgrass, Beardless } \\
\text { Whitmar }\end{array}$ & $\mathrm{M}-\mathrm{H}$ & $\mathrm{M}$ & $\mathrm{H}$ \\
\hline $\begin{array}{l}\text { Wheatgrass, Bluebunch } \\
\text { Goldar }\end{array}$ & $\mathrm{M}$ & $\mathrm{M}-\mathrm{L}$ & $\mathrm{M}-\mathrm{H}$ \\
\hline $\begin{array}{l}\text { Wheatgrass, Crested } \\
\text { Douglas, Fairway, Kirk, Parkway, Ephraim }\end{array}$ & $\mathrm{M}-\mathrm{H}$ & $\mathrm{H}$ & $\mathrm{M}-\mathrm{H}$ \\
\hline $\begin{array}{l}\text { Wheatgrass, Desert crested } \\
\text { Hycrest, Nordan, Summit }\end{array}$ & $\mathrm{M}-\mathrm{H}$ & $\mathrm{H}$ & $\mathrm{M}-\mathrm{H}$ \\
\hline $\begin{array}{l}\text { Wheatgrass, Intermediate } \\
\text { Oahe, Greenar, Rush }\end{array}$ & $\mathrm{H}$ & $\mathrm{H}$ & $\mathrm{M}-\mathrm{H}$ \\
\hline Wheatgrass, Newhy & $\mathrm{M}-\mathrm{H}$ & $\mathrm{M}-\mathrm{H}$ & $\mathrm{M}-\mathrm{H}$ \\
\hline $\begin{array}{l}\text { Wheatgrass, Pubescent } \\
\text { Luna, Manska }\end{array}$ & $\mathrm{M}-\mathrm{H}$ & $\mathrm{H}$ & $\mathrm{M}-\mathrm{H}$ \\
\hline $\begin{array}{l}\text { Wheatgrass, Siberian } \\
P-27 \text {, Vavilov }\end{array}$ & M & $\mathrm{M}-\mathrm{H}$ & $\mathrm{M}-\mathrm{H}$ \\
\hline $\begin{array}{l}\text { Wheatgrass, Snake River } \\
\text { Secar }\end{array}$ & $\mathrm{M}$ & L-M & $\mathrm{M}-\mathrm{H}$ \\
\hline $\begin{array}{l}\text { Wheatgrass, Tall } \\
\text { Alkar, Jose }\end{array}$ & $\mathrm{H}$ & $\mathrm{M}-\mathrm{H}$ & $\mathrm{L}-\mathrm{M}$ \\
\hline $\begin{array}{l}\text { Wheatgrass, Western } \\
\text { Rosanna }\end{array}$ & $M$ & $\mathrm{M}-\mathrm{H}$ & $\mathrm{M}-\mathrm{H}$ \\
\hline $\begin{array}{l}\text { Wheatgrass, Slender } \\
\text { Pryor (short-lived) }\end{array}$ & M & M & $\mathrm{M}-\mathrm{H}$ \\
\hline $\begin{array}{l}\text { Wheatgrass, Streambank } \\
\text { Sodar }\end{array}$ & $\mathrm{L}-\mathrm{M}$ & $M$ & $\mathrm{M}$ \\
\hline $\begin{array}{l}\text { Wheatgrass, Thickspike } \\
\text { Bannock }\end{array}$ & $M$ & $M$ & $\mathrm{M}$ \\
\hline $\begin{array}{l}\text { Wildrye, Great Basin } \\
\text { Magnar, Trailhead }\end{array}$ & $\mathrm{M}-\mathrm{H}$ & L & $L-M$ \\
\hline $\begin{array}{l}\text { Wildrye, Beardless, Creeping } \\
\text { Shoshone }\end{array}$ & $\mathrm{M}$ & $\mathrm{M}-\mathrm{H}$ & $\mathrm{M}$ \\
\hline $\begin{array}{l}\text { Wildrye, Russian } \\
\text { Bozoisky }\end{array}$ & $M$ & $\mathrm{M}-\mathrm{H}$ & M \\
\hline \multicolumn{4}{|l|}{ Forbs and Legumes } \\
\hline $\begin{array}{l}\text { Alfalfa } \\
\text { 2-3 dormancy class }\end{array}$ & $\mathrm{M}-\mathrm{H}$ & M & $\mathrm{H}$ \\
\hline $\begin{array}{l}\text { Birdsfoot trefoil } \\
\text { Empire, Leo, Kalo, Dawn }\end{array}$ & $\mathrm{L}-\mathrm{M}$ & $\mathrm{M}-\mathrm{H}$ & $\mathrm{H}$ \\
\hline $\begin{array}{l}\text { Rose clover } \\
\text { Monte Frio, Overton }\end{array}$ & M & $\mathrm{M}$ & $\mathrm{H}$ \\
\hline \multicolumn{4}{|l|}{ Shrubs } \\
\hline Bitterbrush, Antelope & $M$ & M & $\mathrm{H}$ \\
\hline $\begin{array}{l}\text { Kochia, Forage } \\
\text { Immiarant }\end{array}$ & M & $\mathrm{H}$ & $\mathrm{M}-\mathrm{H}$ \\
\hline
\end{tabular}

* Yield potential ratings are relative to the sites where species are adapted and most commonly seeded.

\section{Soil and Climatic Characteristics of the Site}

It is critical that you select species that are adapted to the soil and precipitation characteristics of the chosen site. A popular species may have several desirable characteristics, but if it is not well-adapted to the site, there is little chance for successful establishment. Annual precipitation is the most common determining factor for which species will successfully establish and persist on a given site. Do not select a species that requires more annual precipitation than is typical for the site. Table 2 lists minimum recommended amounts of average annual precipitation for several common dryland species.

Another important site factor affecting species selection is soil type. In the intermountain region, key soil attributes include texture, depth, and alkalinity. Table 2 shows which soil characteristics are suitable for each listed dryland species. You can get information on local soil characteristics from the Natural Resources Conservation Service (NRCS) soil survey (see contact information under Useful Resources at the end of this publication) in conjunction with on-site evaluations, either performed by you or with assistance from a farm advisor, hired consultant, or NRCS conservationist. You will find more information on important soil attributes in the Site Selection section.

\section{Availability and Cost of Seed}

Seed prices and seed supplies vary from year-to-year depending on production and demand. Typically, native species are more expensive and in shorter supply than common introduced species such as intermediate or crested wheatgrass. Seed cost can be a considerable factor on large projects, and it is not uncommon for a native seed mix to cost more than $\$ 100$ per acre. Although seed can be expensive, it is important that you not use less than the recommended seeding rate in order to meet a budget. When considering costs, always remember that any dryland planting is at the mercy of the weather during the year of establishment. Dry spring weather is not unusual, so when it comes to the cost of seed, decide how much money you are willing to risk in that particular year and bear in mind that a repeat seeding may be necessary in future years. 
Table 2. Adaptations and seeding rates for selected dryland species

\begin{tabular}{|c|c|c|c|c|c|c|c|c|c|c|}
\hline $\begin{array}{l}\text { Forage plant } \\
\text { (recommended varieties/selections } \\
\text { in italics) }\end{array}$ & $\begin{array}{l}\text { Seedling } \\
\text { growth rate }\end{array}$ & Height & $\begin{array}{l}\text { Growth } \\
\text { habit }\end{array}$ & $\begin{array}{l}\text { Native/ } \\
\text { introduced }\end{array}$ & $\begin{array}{l}\text { Seeds } \\
\text { per Ib }\end{array}$ & $\begin{array}{l}\text { Minimum } \\
\text { precipitation* }\end{array}$ & Soil & $\begin{array}{c}\text { Alkali } \\
\text { tolerance }\end{array}$ & $\begin{array}{l}\text { Seeding } \\
\text { depth (in) }\end{array}$ & $\begin{array}{l}\text { PLS } \\
\text { rate }^{\ddagger}\end{array}$ \\
\hline \multicolumn{11}{|l|}{ Grasses } \\
\hline Bluegrass, Big Sherman & slow-medium & medium-tall & bunch & native & 796,000 & $10^{\prime \prime}$ & clay loam-sandy loam & 0 & $1 / 4-1 / 2$ & 3 \\
\hline Bluegrass, Canby Canbar & slow-medium & short-medium & bunch & native & 926,000 & $10^{\prime \prime}$ & clay-sandy loam & 1 & $0-1 / 4$ & 3 \\
\hline Bluegrass, Sandberg & slow-medium & short-medium & bunch & native & 950,000 & $8^{\prime \prime}$ & clay loam-sandy loam & 2 & $0-1 / 4$ & 3 \\
\hline Brome, Meadow Fleet, Paddock, Regar & medium-rapid & medium-tall & bunch & introduced & 80,000 & $16^{\prime \prime}$ & clay loam-sandy loam & 1 & $1 / 4-1 / 2$ & 12 \\
\hline Brome, Mountain Bromar (short-lived) & medium-rapid & tall & bunch & native & 90,000 & $16^{\prime \prime}$ & clay-sandy loam & 1 & $1 / 4-1 / 2$ & 12 \\
\hline Brome, Smooth Lincoln, Manchar & very rapid & tall & sod & introduced & 125,000 & $14^{\prime \prime}$ & clay loam-sandy loam & 2 & $1 / 4-1 / 2$ & 8 \\
\hline Fescue, Idaho Joseph & very slow & medium & bunch & native & 450,000 & $16^{\prime \prime}$ & clay loam-sandy loam & 1 & $1 / 4-1 / 2$ & 3 \\
\hline Foxtail, Creeping meadow Garrison & slow & medium-tall & sod & introduced & 841,000 & $18^{\prime \prime}$ & clay-loam & 1 & $1 / 4-1 / 2$ & 3 \\
\hline Needlegrass, Columbia & slow & medium & bunch & native & 180,000 & $12^{\prime \prime}$ & clay loam-sandy loam & 1 & $1 / 4-1 / 2$ & 7 \\
\hline Needlegrass, Needle \& Thread & slow and thread & medium & bunch & native & 180,000 & $8^{\prime \prime}$ & clay loam-sandy loam & 2 & $1 / 4-1 / 2$ & 7 \\
\hline Orchardgrass Paiute & medium & medium-tall & bunch & introduced & 375,000 & $16^{\prime \prime}$ & clay-sandy loam & 0 & $1 / 4-1 / 2$ & 4 \\
\hline Squirreltail, Bottlebrush Sand Hollow & medium & medium & bunch & native & 190,000 & $8^{\prime \prime}$ & clay loam-sandy loam & 2 & $1 / 4-1 / 2$ & 7 \\
\hline Wheatgrass, Beardless Whitmar & medium & medium & bunch & native & 117,000 & $10 "$ & clay loam-sandy loam & 1 & $1 / 4-1 / 2$ & 8 \\
\hline Wheatgrass, Bluebunch Goldar & medium & medium & bunch & native & 139,000 & $12^{\prime \prime}$ & clay loam-sandy loam & 1 & $1 / 4-1 / 2$ & 8 \\
\hline $\begin{array}{l}\text { Wheatgrass, Crested Douglas, Fairway, } \\
\text { Kirk, Parkway, Ephraim }\end{array}$ & rapid & short-medium & bunch & introduced & 250,000 & $10^{\prime \prime}$ & clay-sandy loam & 2 & $1 / 4-1 / 2$ & 5 \\
\hline $\begin{array}{l}\text { Wheatgrass, Desert crested Hycrest, } \\
\text { Nordan, Summit }\end{array}$ & rapid & medium & bunch & introduced & 175,000 & $8^{\prime \prime}$ & clay-sandy loam & 2 & $1 / 4-1 / 2$ & 7 \\
\hline $\begin{array}{l}\text { Wheatgrass, Intermediate } \\
\text { Oahe, Greenar, Rush }\end{array}$ & rapid & medium-tall & sod & introduced & 90,000 & $12^{\prime \prime}$ & clay loam-sandy loam & 1 & $1 / 4-1 / 2$ & 12 \\
\hline Wheatgrass, Newhy & medium & medium & sod & introduced & 131,000 & $14^{\prime \prime}$ & clay-loam & 3 & $1 / 4-1 / 2$ & 8 \\
\hline Wheatgrass, Pubescent Luna, Manska & rapid & medium-tall & sod & introduced & 80,000 & $11^{\prime \prime}$ & loam-sand & 2 & $1 / 4-1 / 2$ & 12 \\
\hline Wheatgrass, Siberian $P-27$, Vavilov & medium & medium & bunch & introduced & 163,000 & $7 "$ & clay-sandy loam & 1 & $1 / 4-1 / 2$ & 6 \\
\hline Wheatgrass, Snake River Secar & medium & medium & bunch & native & 139,000 & $8^{\prime \prime}$ & clay loam-sandy loam & 1 & $1 / 4-1 / 2$ & 8 \\
\hline Wheatgrass, Tall Alkar, Jose & very rapid & tall & bunch & introduced & 79,000 & $14 "$ & clay-sandy loam & 3 & $1 / 4-3 / 4$ & 12 \\
\hline Wheatgrass, Western Rosanna & medium & medium & sod & native & 96,000 & $12^{\prime \prime}$ & clay loam-sandy loam & 3 & $1 / 4-1 / 2$ & 6 \\
\hline Wheatgrass, Slender Pryor (short-lived) & rapid & medium & bunch & native & 131,000 & $10^{\prime \prime}$ & clay-sandy loam & 2 & $1 / 4-1 / 2$ & 6 \\
\hline Wheatgrass, Streambank Sodar & medium & medium & sod & native & 153,000 & $12^{\prime \prime}$ & clay-loam & 1 & $1 / 4-1 / 2$ & 7 \\
\hline Wheatgrass, Thickspike Bannock & medium & medium & sod & native & 133,000 & $8^{\prime \prime}$ & loam-sand & 1 & $1 / 4-1 / 2$ & 8 \\
\hline Wildrye, Great Basin Magnar, Trailhead & slow & tall & bunch & native & 125,000 & $12^{\prime \prime}$ & silt-sandy loam & 2 & $1 / 4-1 / 2$ & 8 \\
\hline Wildrye, Beardless, Creeping Shoshone & very slow & medium-tall & sod & native & 181,000 & $14 "$ & clay-loam & 3 & $1 / 4-1 / 2$ & 16 \\
\hline Wildrye, Russian Bozoisky & slow & medium & bunch & introduced & 140,000 & $12^{\prime \prime}$ & clay-sandy loam & 2 & $1 / 4-1 / 2$ & 6 \\
\hline \multicolumn{11}{|l|}{ Forbs and Legumes } \\
\hline Alfalfa 2-3 dormancy class & medium & medium & erect & introduced & 225,000 & $14^{\prime \prime}$ & silt-sandy loam & 2 & $1 / 8-1 / 2$ & 5 \\
\hline Birdsfoot trefoil Empire, Leo, Kalo, Dawn & medium & short & decumbent & introduced & 470,000 & $16^{\prime \prime}$ & clay-sandy loam & 3 & $1 / 8-1 / 2$ & 4 \\
\hline Rose clover§ Monte Frio, Overton & rapid & short & erect & introduced & 275,000 & $14^{\prime \prime}$ & clay-sandy loam & 2 & $1 / 8-1 / 2$ & 6 \\
\hline \multicolumn{11}{|l|}{ Shrubs } \\
\hline Bitterbrush, Antelope & slow & $3^{\prime}-7^{\prime}$ & shrub & native & 18,000 & $10^{\prime \prime}$ & clay loam-sandy loam & 1 & $1 / 4-1 / 2$ & 2 \\
\hline Kochia, Forage Immigrant & slow & $1^{\prime}-3^{\prime}$ & half-shrub & introduced & 395,000 & $8^{\prime \prime}$ & clay loam-sandy loam & 3 & $0-1 / 4$ & 1 \\
\hline
\end{tabular}




\section{Introduced Wheatgrasses: the Most Common Choice}

Introduced wheatgrasses (most frequently, intermediate and crested wheatgrass) are the most commonly seeded species in the intermountain region. They tolerate grazing well, adapt to many soil types, and have good seedling vigor, and the seed is almost always available in adequate supply and at a reasonable price. If you are looking for a reliable, affordable choice, choose the best-adapted wheatgrass for your area. On sandy loam soils where precipitation averages 14 or more inches per year, intermediate wheatgrass is usually the best choice. On drier sites, pubescent wheatgrass is often preferred. Crested wheatgrass is the best choice for dry sites with sandy or shallow soils. Most wheatgrass species can be mixed with drought tolerant forbs and shrubs. Table 3 presents some typical seed mixes that are based on introduced wheatgrasses and used with the objective of improving livestock forage.

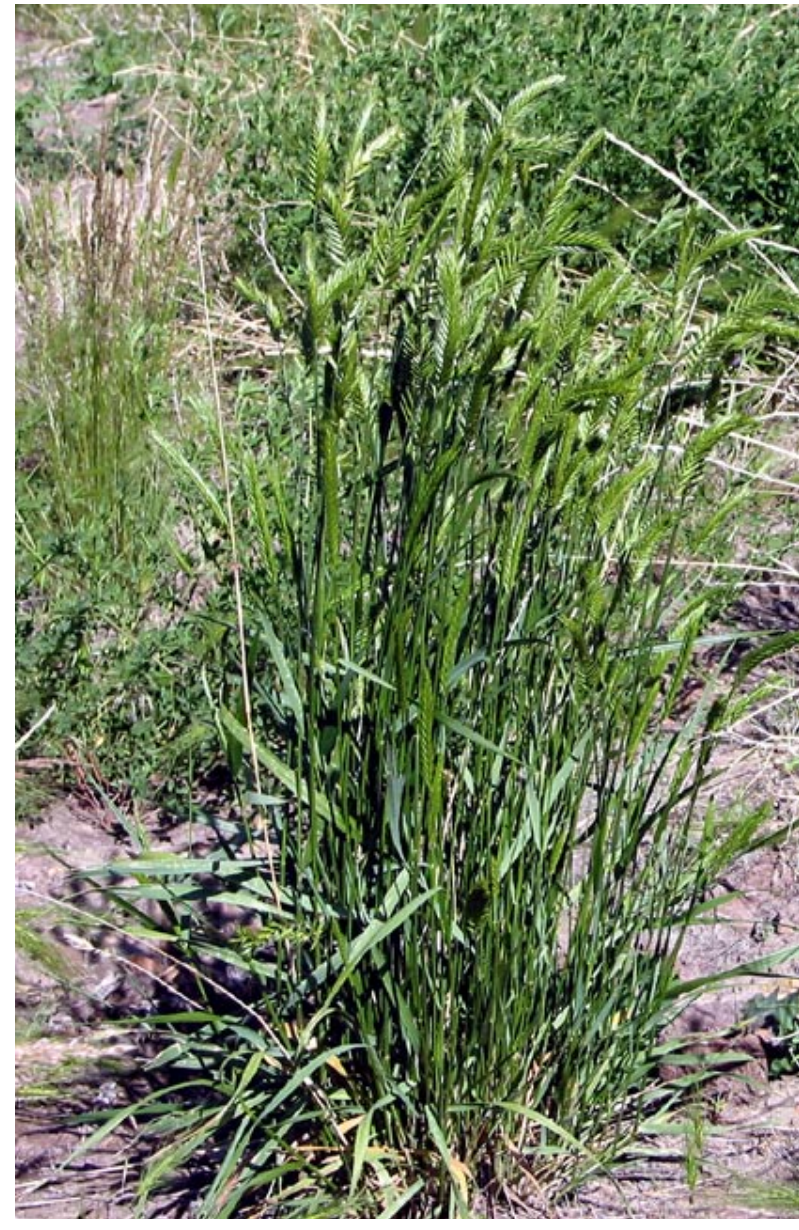

Crested wheatgrass plant.
Photo by Rob Wilson.

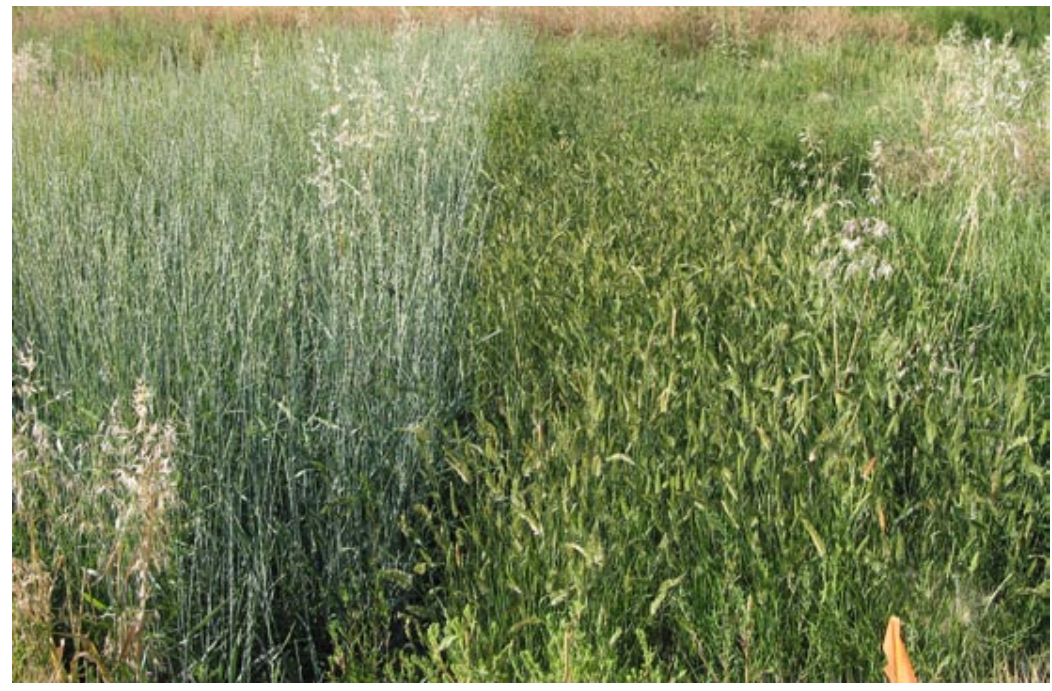

Side-by-side comparison of flowering intermediate wheatgrass (left) and crested wheatgrass (right) in a variety trial in Tulelake, California. Photo by Rob Wilson.

Table 3. Recommended wheatgrass-based mixes and seeding rates for improved livestock forage

\begin{tabular}{|c|c|c|c|}
\hline Precipitation & Soil type & Plant species & Suggested varieties \\
\hline $\begin{array}{l}14+\text { inches per } \\
\text { year }\end{array}$ & $\begin{array}{l}\text { not alkali, } \\
\text { moderate fertility }\end{array}$ & $\begin{array}{l}\text { intermediate wheatgrass: } \\
12 \text { lb/acre } \\
\text { dryland alfalfa: } \\
2 \text { lb/acre }\end{array}$ & $\begin{array}{l}\text { intermediate } \\
\text { wheatgrass: } \\
\text { Oahe, Greenar, Rush } \\
\text { alfalfa: } \\
\text { Ladak, BlazerXL }\end{array}$ \\
\hline $\begin{array}{l}12+\text { inches per } \\
\text { year }\end{array}$ & $\begin{array}{l}\text { not alkali, } \\
\text { low to moderate } \\
\text { fertility }\end{array}$ & $\begin{array}{l}\text { pubescent wheatgrass: } \\
12 \mathrm{lb} / \text { acre } \\
\text { dryland alfalfa: } \\
2 \text { lb/acre }\end{array}$ & $\begin{array}{l}\text { pubescent wheatgrass: } \\
\text { Luna, Manska } \\
\text { alfalfa: } \\
\text { Ladak, BlazerXL }\end{array}$ \\
\hline $\begin{array}{l}12+\text { inches per } \\
\text { year }\end{array}$ & sandy & $\begin{array}{l}\text { crested wheatgrass: } \\
12 \text { lb/acre } \\
\text { dryland alfalfa: } \\
2 \text { lb/acre }\end{array}$ & $\begin{array}{l}\text { crested wheatgrass: } \\
\text { Douglas, Fairway } \\
\text { alfalfa: } \\
\text { Ladak, BlazerXL }\end{array}$ \\
\hline $\begin{array}{l}12+\text { inches per } \\
\text { year }\end{array}$ & $\begin{array}{l}\text { alkali } \\
(\mathrm{pH}>7.9 \\
\left.\text { or } \operatorname{SAR}^{*}>12\right)\end{array}$ & $\begin{array}{l}\text { tall wheatgrass: } \\
12 \text { lb/acre } \\
\text { dryland alfalfa: } \\
2 \text { lb/acre }\end{array}$ & $\begin{array}{l}\text { tall wheatgrass: } \\
\text { Alkar, Jose } \\
\text { alfalfa: } \\
\text { Ladak, BlazerXL }\end{array}$ \\
\hline
\end{tabular}

*Sodium adsorption ratio 


\section{Introduced vs. Native Species}

There is a long-running debate over the benefits of planting introduced versus native plant species. In the early years of range improvement, introduced species were used almost exclusively for rangeland seedings. Introduced species have several general advantages over their native counterparts in terms of seed cost, ease of establishment, and tolerance to grazing. For example, when native and introduced grasses were seeded in trials conducted in Siskiyou and Lassen Counties, introduced wheatgrasses nearly always outperformed native grasses by a substantial margin with regard to seedling survival and establishment (unpublished data). The advantages of high seedling vigor and ease of establishment are especially important on sites that are prone to invasion by noxious weeds such as cheatgrass, medusahead, or yellow starthistle. Restoration ecologists continue to work on methods to improve seeding techniques for native species, but for now, introduced species have a significant advantage over native species with regard to establishment success.

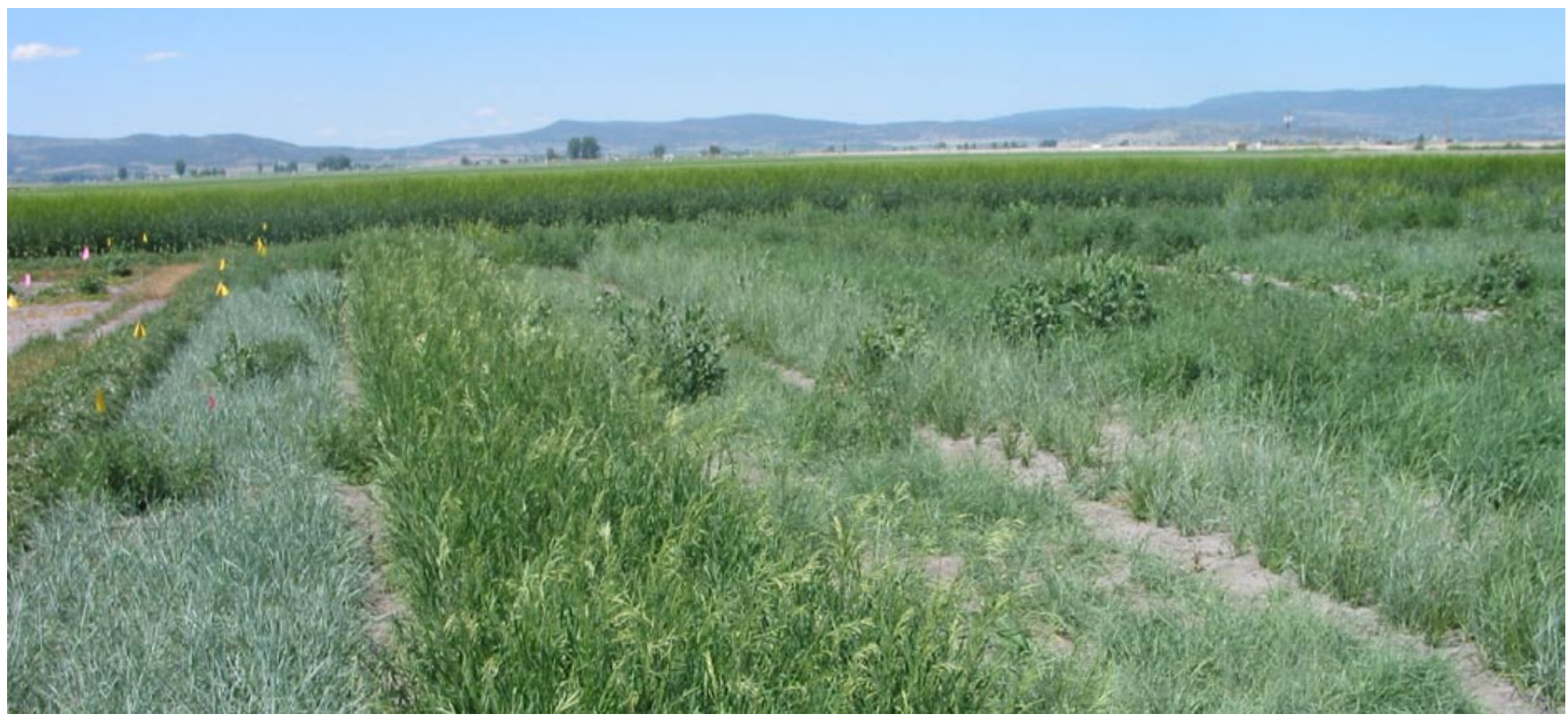

Dryland variety trial in Tulelake, California, showing the wide range of productivity between different native and introduced plant species.

Photo by Rob Wilson.

Proponents of native species point to the inherent benefits of maintaining species that are native to a given region, even though those species may be hard to establish. Native species proponents have two common concerns about planting introduced grasses: the lack of natural recruitment of native forbs and shrubs into stands of introduced grasses, which carries with it a reduction in plant diversity and possibly wildlife habitat; and the species' potential to spread into, and possibly outcompete, nearby native plant communities. The competitive nature of a well-established stand of introduced wheatgrasses may impede the establishment of some native species. However, there is no published research clearly demonstrating that grasses native to intermountain rangelands are measurably more compatible with native shrubs and forbs than are introduced wheatgrasses, nor have introduced wheatgrasses been observed spreading into intact native plant communities. In actuality, there are many places within the intermountain region where sagebrush, juniper, and other native species have moved into established wheatgrass seedings. In any case, it is clear that a well-established stand of perennial cool-season grasses (whether native or introduced) is preferable to the weedy annual grasses or other noxious weeds that typically invade range sites where pasture seedings fail. 


\section{Calculating Seeding Rates on a Pure Live Seed (PLS) Basis}

Assume that a grower wants to seed intermediate wheatgrass at $12 \mathrm{lb}$ PLS per acre, and that the PLS listed on the seed bag is 80 percent. To calculate the actual seeding rate, divide the PLS seeding rate (12 Ib/acre) by the PLS percentage $(80 \%)$ and multiply the result by 100:

$$
12 \div 80 \times 100=15
$$

For this example, the actual seeding rate for intermediate wheatgrass would be $15 \mathrm{lb}$ per acre.

\section{Seed Mixes vs. Single Species}

Seeding recommendations vary from single grass species to complex seed mixes. Mixes are an attractive choice because they address variations in soil characteristics and provide a diversity of species that offer various benefits to livestock, wildlife, and the suppression of weeds. Managing a seed-mix planting can be quite complicated, however, especially when it comes to weed control and livestock management. On a relatively small (less than 40 acres) homogenous site, a single grass species or a simple mix of a single grass and a forb is often adequate. Single-species plantings are easy to manage and can supply livestock with needed forage. Single-species pastures also allow managers to choose from a wide range of herbicides that they can safely apply for weed control. They also eliminate the potential for uneven livestock grazing based on the animals' preference of one plant species over the other.

Large seedings that feature more variation in soils may warrant a more complex species mix. Subtle differences in soil and microclimate can be enough to favor one species over another, so by seeding a mixture of several species you can often improve the odds that at least a couple of species will establish over the entire landscape. Furthermore, by planting mixes you can improve biodiversity across the landscape. When deciding on which species to include in a seed mix, choose plants with similar levels of seedling vigor, maturity dates, tolerance to grazing, and palatability. A species mix that varies too widely in these characteristics will usually yield a field where grazing preferences can lead to overgrazing and loss of the most palatable species.

\section{Seeding Rates}

Seeding rates vary depending on plant species, site conditions, and seeding methods. Table 2 provides recommended seeding rates for several dryland forage species, assuming optimal site and seeding conditions. When broadcasting seed onto rough or rocky terrain, you may want to increase the seeding rate to help compensate for an unavoidable lack of uniformity in seed placement. If weeds are a problem, you can try increasing the seeding rate to improve weed suppression after grass establishment, but you will still need to control weeds throughout the establishment phase. Although increases in the seeding rate can be beneficial, they are no substitute for proper establishment practices. Excessively high seeding rates can even result in the failure of a stand. Soil moisture is a limiting factor, and a high seeding rate can lead to high seedling mortality as plants of the desired species compete with one another for that moisture.

Actual seeding rates should be based on the Pure Live Seed Percentage (PLS). PLS is a computation that reflects the germination and purity (to species) of a seedlot where a PLS of 100 percent equals 100 percent germination and purity. Referring to PLS, you can accurately compare different seed prices and know that you are sowing at the correct seeding rate. To determine the PLS for a seedlot (bag of seed), you multiply the seed germination percentage by its purity percentage and then divide by 100 . Germination and purity percentages are listed on the seed bag along with percentages of weed seed and inert matter. Avoid buying seed that contains noxious weeds or high levels of inert matter and aim for a PLS above 80 percent. To convert the recommended PLS seeding rate to a bulk seeding rate, divide the PLS seeding rate by the seedlot's PLS percentage and then multiply by 100 .

- $\operatorname{PLS} \%=(\%$ germination $) \times(\%$ purity $) \div 100$

- Seeding rate of bulk seed $=($ recommended PLS seeding rate $) \div($ PLS \% $) \times 100$ 


\title{
SITE PREPARATION AND PLANTING METHODS
}

\author{
Steve Orloff and Rick Delmas
}

The methods used to prepare a dryland pasture site for seeding can determine the outcome-whether you end up with a successful seeding or a crop failure. Adequate rainfall and soil moisture are absolutely critical to the success of dryland pasture establishment. Because of general local climatic conditions and the inconsistent patterns of spring rainfall, dryland seedings in the intermountain region fail more often as a result of inadequate soil moisture than for any other reason. It is not uncommon for about two out of five attempts at dryland seeding to fail due to inadequate precipitation. The planting system you use, including the type or degree of tillage for site preparation, seeding date, and seeding method, also has a profound influence on soil moisture content and the likelihood that your dryland seeding will be a success.

\section{Planting Date}

It is important to seed at those times of the year when there is the greatest probability that enough rain will fall after seeding to get the stand established. For this reason, two times to avoid seeding are late spring and summer. Dryland pastures can be successfully seeded in late fall, winter, or early spring. There are advantages and disadvantages associated with each planting window.

\section{Fall}

The fall seeding period runs from September to early November. Seeding at this time takes advantage of growth during the coolest, wettest time of year, when plant water needs are low. By seeding perennial grass at this time, you can give the plants a better opportunity to become established before moisture stress occurs. There are several risks and problems associated with seeding in both early and late fall, however.

Early fall seeding. A dryland pasture crop seeded early in the fall can fail if there is sufficient rainfall for germination in early fall but it is followed by an extended dry period. The seed germinate with the initial rainfall, but can then desiccate and die if no subsequent rainfall comes soon enough.

Late fall seeding. The chances of more continuous rainfall are greater for seedings made later in the fall. When you seed late in the fall, however, temperatures may be so cold that plants cannot germinate or become well established before the onset of winter. On some soil types there is a risk of frost heaving (uprooting) of small seedlings as a result of winter freeze-and-thaw cycles. An additional problem with fall seedings is that winter annual weeds, particularly grasses, generally emerge at the same time as the plants you have seeded. Winter annual weeds grow rapidly, often outcompeting perennial grass seedlings, and unfortunately there are few ways to control these weeds after crop emergence (see the Weed Control section). Despite the risks and the potential for weed problems, fall may be the best time to seed a dryland pasture, especially in areas where the soil is too wet for planting in spring. Seeding in late fall also works best on alkali soils, where it allows seeds to take full advantage of the diluting effect of winter moisture and waterlogged soil conditions.

\section{Winter (or "Frost") Planting}

Seeding during the winter months is not common in Northern California's intermountain region. In winter, the soil is often frozen or so wet that you can't get seeding equipment into the fields. Winter temperatures are typically too low for germination, so even if you do apply seeds they probably will not germinate until late winter or spring when soil temperatures rise to adequate levels for germination. 


\section{Late Winter/Early Spring}

The best time for seeding in many areas of the intermountain region comes in late winter and early spring. The optimal seeding time depends on the pasture's location and on current and predicted weather conditions. The seeding window typically runs from mid-February to late March-toward the earlier end of this range in warm areas and later in cooler areas. The advantage of this planting period is that most of the winter annual weeds have already emerged and can therefore be controlled with cultivation or a nonselective herbicide. The primary risk associated with this timing comes when there is a dry spring.

\section{Seedbed Preparation}

\section{Tilled System}

Tillage may or may not be necessary for a dryland seeding, depending on soil conditions, what weeds are present, and what tillage equipment is available to you. Plowing or ripping to prepare a seedbed is common for most field and vegetable crops but rare for dryland seeding because the economic returns normally do not justify the cost of intensive tillage. In addition, the soil in many dryland pasture sites is too rocky or too shallow to allow any type of deep tillage. Disking or harrowing will usually suffice. This sort of less-intensive tillage serves to loosen the soil enough to let the planter place the seed at the proper depth and cover it with soil. Disking or harrowing also help control weeds that may have emerged before the time of planting.

The biggest disadvantage of tillage involves soil moisture-especially for late winter to spring seedings. Soils at this time of year are often too wet to allow any type of tillage operation. If you feel it is necessary to till before you plant, you have to delay your planting date until the soil has dried enough to allow tillage. This may delay planting beyond the most desirable period and soil moisture may become too scarce when the grasses are trying to get established. In addition, when you till a field it loses much of its soil moisture through evaporation. That means the crop will require rainfall after seeding just to allow the seeds to germinate and to settle the seedbed. One way to minimize soil moisture losses during spring tillage and seeding is to work one day at a time, tilling only the amount of land you can plant that same day. When you prepare a seedbed and plant it on the same day, you can plant the seeds directly into the soil moisture that tillage has brought to the surface. This strategy does have disadvantages, though: you have to pack the soil immediately after tillage in order to achieve a firm seedbed, and there is the hassle associated with switching every day between tillage and seeding activities. A firm seed bed is important: it keeps the seed from being planted too deep and provides good seed-to-soil contact, so if the seed drill is not equipped with press wheels you will want to use a cultipacker behind the drill.

Extensive leveling is not usually necessary in dryland seedings simply because the field will not be irrigated and problems with puddling or dry spots are not likely. Rainfall usually applies water more slowly than sprinklers or flood irrigation. If you do not intend to cut the dryland field's forage for hay, a smooth surface to run equipment over becomes less critical.

\section{No-Till System}

Rough or rocky terrain makes tillage unfeasible in some dryland locations, but land managers have good results from no-till systems on such sites. A no-till system has several advantages: the seeding operation is generally less expensive since planting consists of a single trip across the field; this also makes seeding a much quicker operation; and you can plant by the no-till method on soil that is too wet for cultivation. 


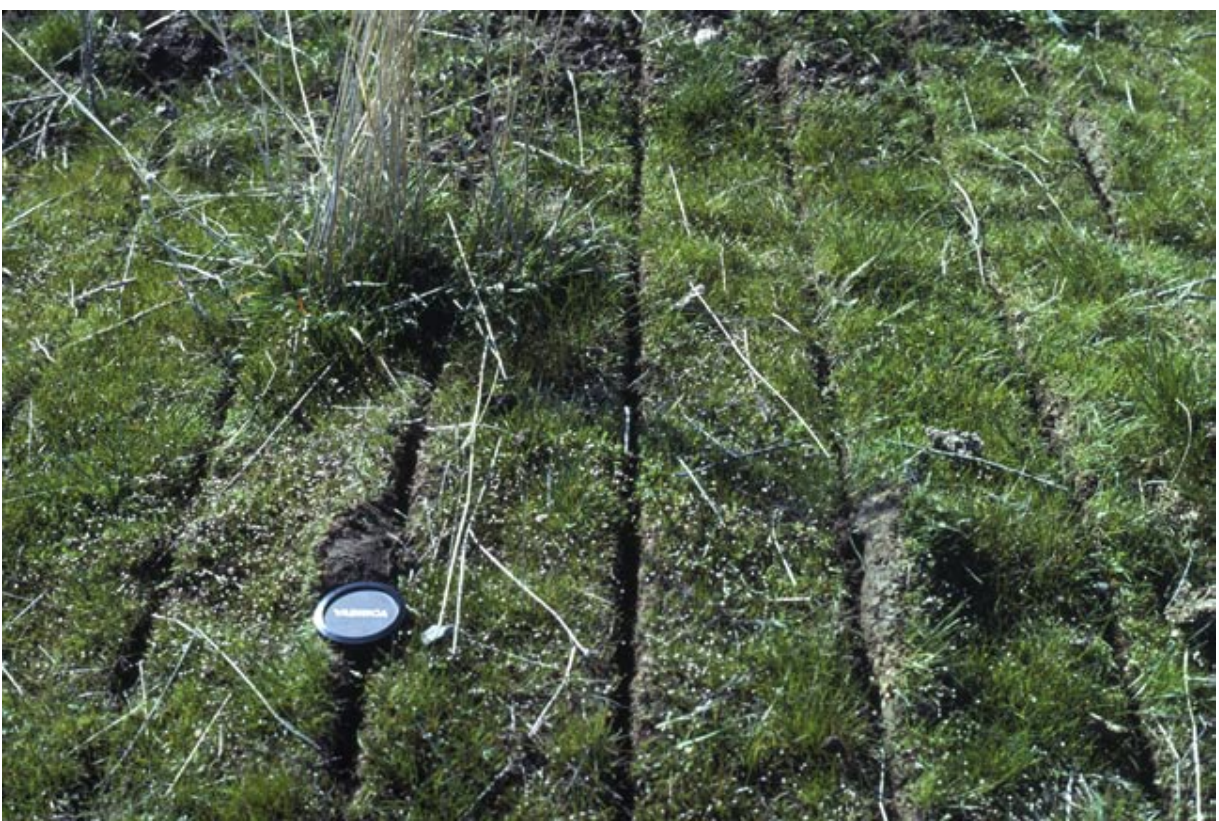

Drill rows after a no-till seeding. Notice that the no-till drill penetrated through the sod to provide good seed-to-soil contact.
Timely planting into moist soil is particularly important for late spring plantings since the plants must germinate and become established before rainfall diminishes or ceases entirely. Not only does a notill system allow you to plant into wetter soil, the soil actually loses less moisture because you leave it nearly undisturbed. The disadvantage of no-till seeding is that you may have to use a specialized notill drill to penetrate the soil to the desired planting depth. These drills are relatively expensive and may not be available to rent or lease. Growers generally apply some form of pre-plant chemical weed control to no-till plantings in order to prevent established weeds from crowding out young grasses. When herbicides are applied prior to a no-till seeding, however, weeds typically establish at a lower density than when the seeding follows cultivation.

\section{Combined Tillage/No-Till System}

One of the most effective approaches used in the intermountain area involves a combination of tillage and no-till systems. This method takes advantage of many of the strong points mentioned above for each system. The grower prepares the field in fall as if it were to be planted at that time. The field is left bare, however, going into the winter, and winter rains firm the field to create a favorable seed bed. Winter rains also stimulate the emergence of winter annual weeds. The grower then controls these weeds with a nonselective contact herbicide such as glyphosate (Roundup) or paraquat (Gramoxone) before planting. Then the field is no-till seeded. A conventional grain drill is ordinarily sufficient for the job, as the soil was tilled in the fall and remains soft enough for a conventional drill to penetrate.

In most years there is a break in winter weather-when precipitation temporarily stops and temperatures warm slightly-sometime in February or early March, depending on the year and the area. This typically provides an opportunity for the grower to spray and seed the fields before precipitation and cooler temperatures return.
Photo by Rob Wilson.
Late winter no-till planting using an experimental drill into a seedbed that was disked and packed the previous fall. 
There are several advantages to this combination method. The seedbed is usually in excellent condition at seeding time. Planting generally does not require the less-common no-till drill. You can usually plant earlier in late winter because you do not need the soil to dry out enough for seedbed preparation. This last point is critical, since it means the plants will have more time to become established before spring rains end and moisture becomes a limiting factor. Weed competition stays at a minimum because you control weeds just before planting and there is almost no subsequent soil disturbance.

\section{Seeding Method}

The key points with any seeding system are to place the seed at the proper soil depth for optimal emergence, to have good seed-to-soil contact so the germinating seedlings will not dry out, and to minimize competition from weeds. The proper planting depth depends on the plant species, the size of the seed, local soil characteristics, and the anticipated frequency and amount of

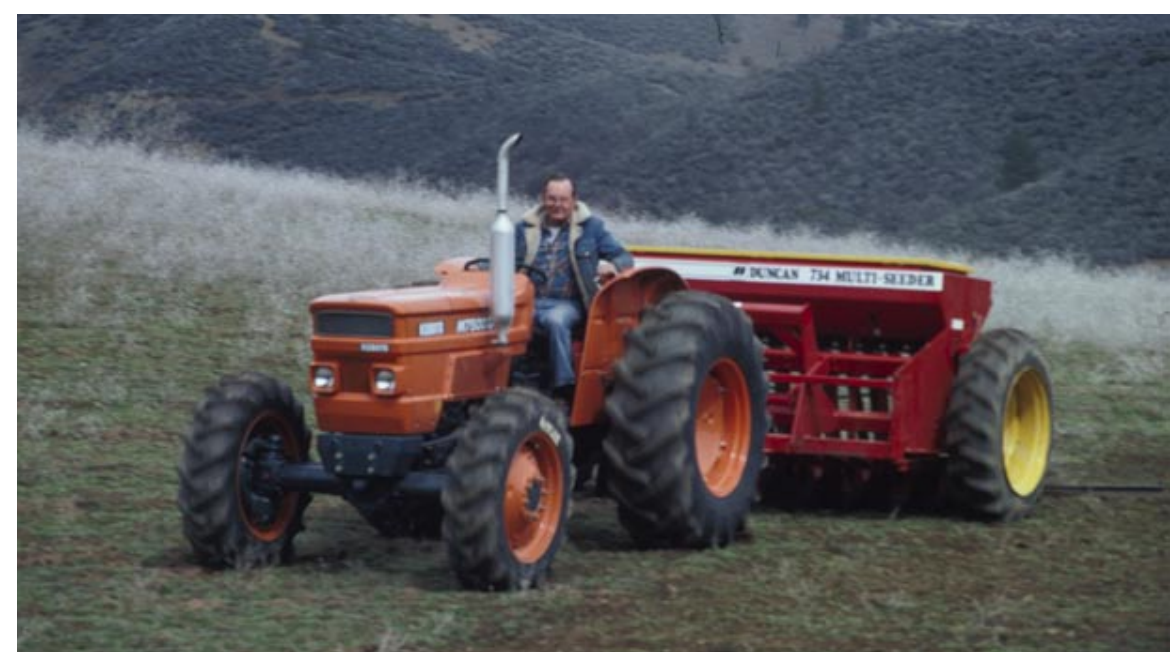

Drill-seeding perennial grass pasture in Siskiyou County.

Photo by Dan Drake.

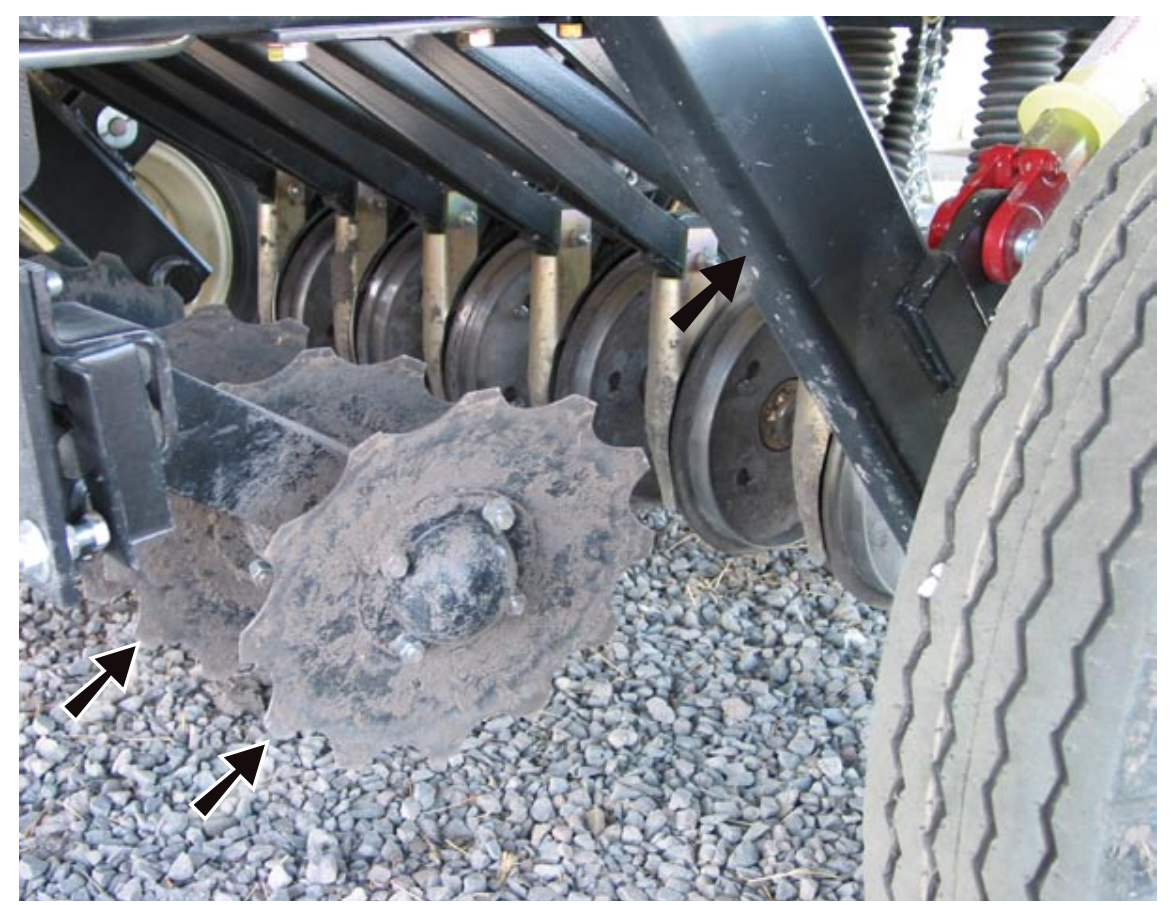

Trash coulters mounted in front of the double-disk opener on a no-till drill. Trash coulters cut through sod and litter to achieve proper seed placement in the soil. rain. Planting seeds at the wrong depth is a common cause of seeding failures. In general, the best planting depth for most dryland seedings is from $3 / 8$ to $5 / 8$ inch, but large-seeded grasses like wheatgrasses are best planted $1 / 3$ to $2 / 3$ inch deep on medium- or heavy-textured soil. A greater depth, $3 / 4$ to $1 \frac{1 / 4}{4}$ inches, may be better for sandy soils because the surface is so quick to dry out. Shallower seeding is appropriate in any soil if you anticipate frequent rainfall throughout the germination and emergence periods.

Drilling the seed using the small seed box of a conventional grain drill or a specialized no-till drill suitable for range seedings gives better results than simply broadcasting the seed. Drilling allows for more precise seed placement and more favorable seed-to-soil contact. Drilling also allows a no-till approach, whereas broadcasting does not. In addition, the disc openers of a drill can sometimes create a mini-furrow that collects moisture and aids with germination.

It often happens that no suitable drill is available to seed a very small area (a few acres or less). Although a drill is strongly preferred, in this situation you can go ahead and broadcast the seed. To maximize the success of a broadcast seeding, till and pack the field prior to seeding. Use a disc or harrow (or a rotary tiller for small areas) to till the soil and then use a cultipacker or roller to firm the soil. After broad- 
casting, incorporate the seed approximately $1 / 2$ inch deep into the soil using a cultipacker, ringroller, or some other type of roller.

In areas where you want to improve the forage production but physical conditions (e.g., rocks or steep slopes) preclude the use of seed-drilling equipment, consider broadcast-seeding annual clovers. Most annual clovers will not do well in the intermountain region, but two varieties of rose clover, Monte Frio and Overton, have a good history in intermountain locations with mild climates. The best time to broadcast rose clover is in late fall or winter.

Another seeding option is to plant alfalfa or clovers into established grass stands. Legumes are planted to increase the nutritional quality of the forage mix and enhance soil nitrogen levels through their nitrogen-fixing abilities. When you inter-seed clovers in a pasture, they will only establish in bare spots that are void of perennial grasses. The likelihood that you will be able to introduce clovers into fully sodded areas is poor. Pastures that are partially degraded and show increasing areas of bare soil are the best candidates for inter-seeding with legumes. The presence of legumes in a dryland pasture can complicate your selection of an herbicide for weed control. Many herbicides that control broadleaf weeds also cause unacceptable injury to alfalfa and clovers. See the Weed Control section for further details on herbicides.

\section{Supplemental Irrigation during Establishment}

As mentioned above, inadequate moisture is the most common obstacle to success for dryland seedings. As the name "dryland" indicates, irrigation is unavailable at most sites. At some sites, though, irrigation is feasible on a temporary basis during stand establishment. Supplemental irrigation can often help ensure a successful seeding even in a drought year. One or two properly timed irrigations in the spring or early summer can make the difference between successful establishment and failure.

\section{WEED CONTROL}

\section{Rob Wilson and Steve Orloff}

\section{Weed Control during Pasture Establishment}

Weeds are a main cause for failure in dryland seedings, as well as erratic, slow stand development. Competitive weeds starve perennial seedlings of soil moisture, nutrients, and sun-

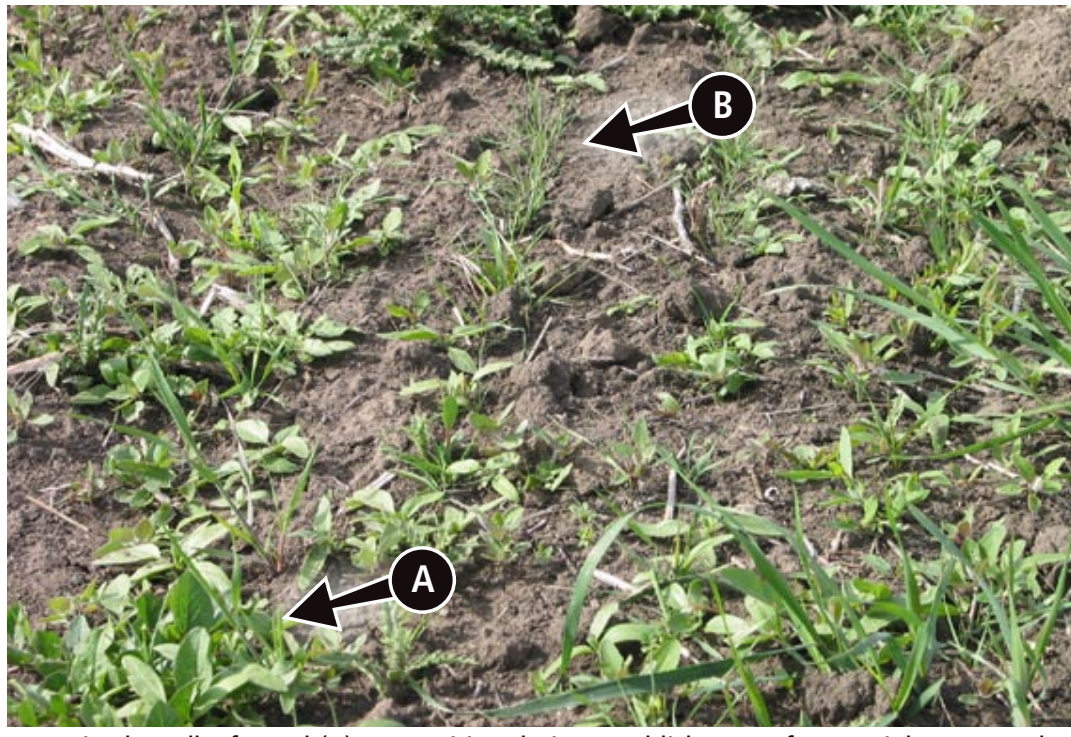

Excessive broadleaf weed (A) competition during establishment of perennial grass seedlings (B). light, and so reduce the seedlings' capacity for survival and growth. Poor weed control during stand establishment also allows the weeds to mature and set seed, setting the stage for future weed problems for years to come. To prevent weeds from overtaking new plantings, identify potential weed problems the year before seeding and aggressively control them at planting and throughout the first growing season. Purchase certified seed that is free of noxious weed seeds and clean all equipment before it enters the field: these two measures help prevent the introduction of weeds during pasture establishment.

Because many troublesome weeds germinate in fall or winter, seeding in late winter (late February to mid-March) offers the best opportunity to keep weed problems to a 
minimum during establishment. You can use tillage or herbicides the fall before planting to control existing biennial and perennial weeds growing on the site and apply glyphosate (Roundup) immediately before planting to effectively control winter annual weeds that have germinated in the fall and winter. When rhizomatous (root-creeping) perennials such as Canada thistle or whitetop are present on the site, implement necessary control measures during the year or growing season before seeding. Often a late spring or fall herbicide treatment will suppress perennial weeds for one to two years, allowing sufficient time for successful pasture establishment in the interim. A list of common problem weeds in the intermountain region showing their susceptibility to herbicides is presented in Table 4 .

Table 4. Weed susceptibility to herbicides labeled for use in rangeland and pasture

\begin{tabular}{|c|c|c|c|c|c|c|c|c|c|c|c|c|c|}
\hline $\begin{array}{l}\text { Control ratings: } \\
C=\text { control } \\
P=\text { partial control or suppression } \\
N=\text { no control } \\
-=\text { no information }\end{array}$ & 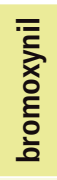 & 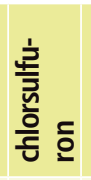 & 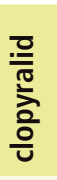 & 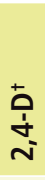 & 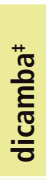 & 옴 & 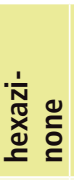 & $\begin{array}{l}\bar{E} \\
\frac{U}{0} \\
\frac{N}{N} \\
\text { E } \\
.\end{array}$ & $\frac{\mathbb{U}}{\Sigma}$ & $\begin{array}{l}\frac{\pi}{\pi} \\
\frac{\pi}{0} \\
\frac{\pi}{\pi} \\
\frac{\pi}{2}\end{array}$ & 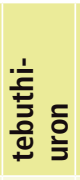 & 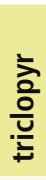 & 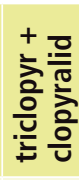 \\
\hline Big sagebrush & $\mathrm{N}$ & $\mathrm{N}$ & $\mathrm{N}$ & $\mathrm{C}$ & $\mathrm{P}$ & $\mathrm{N}$ & $\mathrm{N}$ & $\mathrm{N}$ & - & $\mathrm{N}$ & C & $\mathrm{N}$ & $\mathrm{N}$ \\
\hline Bull thistle & $\mathrm{N}$ & C & $\mathrm{C}$ & $\mathrm{C}$ & $\mathrm{C}$ & C & $P$ & $\mathrm{C}$ & $P$ & $P$ & C & $\mathrm{C}$ & C \\
\hline Bur buttercup & $\mathrm{P}$ & C & $\mathrm{N}$ & $P$ & $\mathrm{C}$ & C & - & $\mathrm{C}$ & $P$ & $P$ & C & - & - \\
\hline Canada thistle & $\mathrm{N}$ & C & C & $P$ & $\mathrm{C}$ & C & $\mathrm{N}$ & $\mathrm{P}$ & $P$ & $\mathrm{~N}$ & $P$ & $P$ & C \\
\hline Cocklebur & $P$ & C & C & $\mathrm{C}$ & $\mathrm{C}$ & C & C & $\mathrm{C}$ & $\mathrm{C}$ & C & C & - & C \\
\hline Dalmation or yellow toadflax & $\mathrm{N}$ & $P$ & $\mathrm{~N}$ & $\mathrm{~N}$ & $\mathrm{~N}$ & $P$ & $\mathrm{~N}$ & $\mathrm{C}$ & $\mathrm{N}$ & $\mathrm{N}$ & N & $\mathrm{N}$ & N \\
\hline Diffuse knapweed & $\mathrm{N}$ & $\mathrm{N}$ & C & $\mathrm{C}$ & $\mathrm{C}$ & $P$ & $\mathrm{~N}$ & $\mathrm{~N}$ & $P$ & $\mathrm{~N}$ & C & $\mathrm{N}$ & C \\
\hline Downy brome/cheatgrass & $\mathrm{N}$ & $\mathrm{N}$ & $\mathrm{N}$ & $\mathrm{N}$ & $\mathrm{N}$ & C & C & $\mathrm{C}$ & $\mathrm{N}$ & C & C & $\mathrm{N}$ & N \\
\hline Dyers woad & $\mathrm{N}$ & C & $\mathrm{N}$ & $P$ & $\mathrm{C}$ & C & C & $\mathrm{C}$ & $P$ & $\mathrm{~N}$ & - & $P$ & $P$ \\
\hline Fiddleneck & $\mathrm{C}$ & C & $\mathrm{N}$ & $\mathrm{P}$ & $\mathrm{C}$ & C & C & $\mathrm{C}$ & $P$ & $P$ & C & - & - \\
\hline Field bindweed & $\mathrm{N}$ & $\mathrm{N}$ & $\mathrm{N}$ & $P$ & $P$ & $P$ & $\mathrm{~N}$ & $\mathrm{P}$ & $\mathrm{N}$ & $\mathrm{N}$ & N & $P$ & $P$ \\
\hline Filaree & $\mathrm{N}$ & - & $P$ & $\mathrm{C}$ & $\mathrm{C}$ & C & C & $\mathrm{C}$ & $P$ & $P$ & C & $P$ & $P$ \\
\hline Hoary cress/whitetop & $\mathrm{N}$ & C & $\mathrm{N}$ & $P$ & $\mathrm{P}$ & $P$ & $\mathrm{~N}$ & $\mathrm{P}$ & $P$ & $\mathrm{~N}$ & $\mathrm{~N}$ & - & - \\
\hline Kochia & $C$ & $P$ & $\mathrm{~N}$ & $P$ & $\mathrm{C}$ & C & C & $\mathrm{C}$ & $P$ & C & $P$ & - & - \\
\hline Medusahead & $\mathrm{N}$ & $\mathrm{N}$ & $\mathrm{N}$ & $\mathrm{N}$ & $\mathrm{N}$ & C & C & $\mathrm{C}$ & $\mathrm{N}$ & C & - & $\mathrm{N}$ & N \\
\hline Musk thistle & $\mathrm{N}$ & C & $\mathrm{C}$ & $\mathrm{C}$ & $\mathrm{C}$ & C & $P$ & $\mathrm{C}$ & $P$ & $P$ & C & - & C \\
\hline Mustards (annual) & $C$ & C & $\mathrm{N}$ & $\mathrm{C}$ & $\mathrm{C}$ & C & C & $\mathrm{C}$ & $\mathrm{C}$ & $P$ & C & - & - \\
\hline Perennial pepperweed & $\mathrm{N}$ & C & $\mathrm{N}$ & $C$ & $\mathrm{P}$ & C & $\mathrm{N}$ & $\mathrm{C}$ & $P$ & $\mathrm{~N}$ & $P$ & $\mathrm{P}$ & $P$ \\
\hline Poison hemlock & $\mathrm{N}$ & C & $\mathrm{N}$ & $C$ & $\mathrm{C}$ & C & $\mathrm{N}$ & $\mathrm{C}$ & $\mathrm{C}$ & $\mathrm{N}$ & C & - & - \\
\hline Poverty weed & $\mathrm{N}$ & - & $\mathrm{N}$ & $P$ & $\mathrm{C}$ & N & $\mathrm{N}$ & - & - & $N$ & C & - & - \\
\hline Prickly lettuce & $C$ & C & $P$ & $C$ & $\mathrm{C}$ & C & C & $\mathrm{N}$ & $C$ & $P$ & C & $C$ & C \\
\hline Puncturevine & $P$ & C & $\mathrm{N}$ & $C$ & $C$ & C & C & $\mathrm{C}$ & $C$ & $P$ & C & - & - \\
\hline Rabbit brush & $\mathrm{N}$ & - & $\mathrm{N}$ & $C$ & $\mathrm{C}$ & $\mathrm{N}$ & $\mathrm{N}$ & $\mathrm{N}$ & - & $\mathrm{N}$ & - & - & - \\
\hline Ripgut brome & $\mathrm{N}$ & $\mathrm{N}$ & $\mathrm{N}$ & $\mathrm{N}$ & $\mathrm{N}$ & C & $P$ & $\mathrm{C}$ & $\mathrm{N}$ & - & C & $\mathrm{N}$ & N \\
\hline Russian knapweed & $\mathrm{N}$ & $\mathrm{N}$ & C & $\mathrm{P}$ & $P$ & $P$ & $\mathrm{~N}$ & $P$ & $\mathrm{~N}$ & $N$ & $P$ & - & C \\
\hline Russian thistle & $C$ & C & $\mathrm{N}$ & $C$ & $C$ & C & C & $\mathrm{C}$ & $P$ & $C$ & - & $P$ & - \\
\hline Sandbur & $\mathrm{N}$ & $\mathrm{N}$ & $\mathrm{N}$ & $\mathrm{N}$ & $\mathrm{N}$ & C & C & $\mathrm{C}$ & $\mathrm{N}$ & $P$ & - & $\mathrm{N}$ & N \\
\hline Scotch thistle & $\mathrm{N}$ & C & C & C & $\mathrm{C}$ & C & $P$ & $P$ & $P$ & $\mathrm{~N}$ & C & $\mathrm{N}$ & C \\
\hline Spotted knapweed & $\mathrm{N}$ & - & C & $C$ & $\mathrm{C}$ & C & - & $\mathrm{N}$ & - & $P$ & C & - & C \\
\hline Squarrose knapweed & $\mathrm{N}$ & - & $\mathrm{C}$ & $\mathrm{C}$ & $\mathrm{C}$ & C & - & $\mathrm{N}$ & - & $P$ & C & - & C \\
\hline Tarweeds & $C$ & C & - & $C$ & $\mathrm{C}$ & C & - & - & $\mathrm{C}$ & $P$ & C & - & - \\
\hline Turkey mullein & $\mathrm{N}$ & C & $\mathrm{N}$ & $P$ & $P$ & $P$ & $P$ & $\mathrm{~N}$ & $\mathrm{~N}$ & $P$ & C & - & - \\
\hline Yellow starthistle & $C$ & $P$ & $\mathrm{C}$ & $\mathrm{C}$ & $\mathrm{C}$ & C & C & $\mathrm{N}$ & $P$ & $\mathrm{C}$ & C & $P$ & $\mathrm{C}$ \\
\hline
\end{tabular}

*Herbicide control ratings assume herbicides are applied at the proper application time according to label instructions. Adding a non-ionic surfactant will often improve post-emergent control.

${ }^{\dagger} 2,4-D$ ester or amine is an active ingredient in many products.

*Dicamba is the active ingredient in many products including Banvel, Clarity, and Vanquish.

$\S$ Glyphosate is the active ingredient in many products including Roundup.

"Imazapic is not labeled for use in California 
If weeds become a problem after planting, you can control them using herbicides or mowing. Several post-emergent herbicides are labeled for broadleaf weed control in grass seedlings (Table 5), but unfortunately no herbicides are currently labeled in California for control of annual grasses (cheatgrass, medusahead, hare barley, etc.). Mowing annual grasses at flowering may prevent excessive shading of the forage crop, but in most cases the weeds will quickly grow back again. If you do mow, set the mower height at approximately 3 inches and repeat the mowing operation as the weeds re-grow. However, do not mow if the forage grasses are so tall that mowing removes more than 50 percent of their leaves.

Table 5. Herbicides labeled for use in rangeland and pasture

\begin{tabular}{|c|c|c|c|}
\hline $\begin{array}{l}\text { Herbicide } \\
\text { (and trade name) }\end{array}$ & $\begin{array}{l}\text { Product rate } \\
\text { per acre }\end{array}$ & Labeled sites & Use/application time \\
\hline $\begin{array}{l}\text { 2,4-D ester or amine } \\
2,4-D 4 L\end{array}$ & $0.5-2.0 \mathrm{qt}$ & $\begin{array}{l}\text { Pasture, } \\
\text { non-cropland }\end{array}$ & $\begin{array}{l}\text { Seedling and established grass. Use } 1.0 \mathrm{pt} / \mathrm{A} \text { rate on } \\
\text { seedling grasses after five-leaf stage. }\end{array}$ \\
\hline $\begin{array}{l}\text { Bromoxynil } \\
\text { Buctril }\end{array}$ & $1.5-2.0 \mathrm{pt}$ & $\begin{array}{l}\text { Alfalfa, } \\
\text { non-cropland; } \\
\text { grass for seed } \\
\text { production }\end{array}$ & $\begin{array}{l}\text { Grass and legume establishment } \\
\text { Apply after three-leaf stage on grass and legume seedlings. } \\
\text { Works best when weeds are small seedlings. }\end{array}$ \\
\hline $\begin{array}{l}\text { Chlorsulfuron } \\
\text { Telar }\end{array}$ & $0.25-1.3 \mathrm{oz}$ & $\begin{array}{l}\text { Non-cropland, } \\
\text { permanent pasture }\end{array}$ & $\begin{array}{l}\text { Pre- and post- emergent weed control in established grass } \\
\text { stands } \\
\text { Read label for grass safety. } \\
\text { Persistent in high pH soils within low rainfall areas }\end{array}$ \\
\hline $\begin{array}{l}\text { Clopyralid } \\
\text { Transline }\end{array}$ & $0.25-0.67 \mathrm{pt}$ & $\begin{array}{l}\text { Pasture, } \\
\text { non-cropland }\end{array}$ & $\begin{array}{l}\text { Weed control in established grass stands } \\
\text { Provides good control of thistles. }\end{array}$ \\
\hline $\begin{array}{l}\text { Dicamba } \\
\text { Banvel, Clarity, } \\
\text { Vanquish }\end{array}$ & $0.25-4.0 \mathrm{pt}$ & $\begin{array}{l}\text { Pasture, } \\
\text { non-cropland }\end{array}$ & $\begin{array}{l}\text { Seedling and established grass. Use } 0.5 \mathrm{pt} / \mathrm{A} \text { rate on } \\
\text { seedling grasses after five-leaf stage. }\end{array}$ \\
\hline $\begin{array}{l}\text { Glyphosate } \\
\text { Roundup, Glyfos, } \\
\text { Glyphomax }\end{array}$ & $0.5-3.0 \mathrm{qt}$ & $\begin{array}{l}\text { Pasture, } \\
\text { non-cropland }\end{array}$ & $\begin{array}{l}\text { Weed control before or at planting } \\
\text { Apply before desired plants emerge. } \\
\text { Use low rate for annual weeds and higher rates for } \\
\text { perennials. }\end{array}$ \\
\hline $\begin{array}{l}\text { Hexazinone } \\
\text { Velpar DF, } \\
\text { Pronone pellet }\end{array}$ & $0.3-2.0 \mathrm{lb}$ & $\begin{array}{l}\text { Pasture, } \\
\text { alfalfa; } \\
\text { non-cropland }\end{array}$ & $\begin{array}{l}\text { Weed and brush control in established pasture and non- } \\
\text { crop areas }\end{array}$ \\
\hline $\begin{array}{l}\text { Imazapic } \\
\text { Plateau }\end{array}$ & $2.0-12.0 \mathrm{oz}$ & $\begin{array}{l}\text { Pasture, } \\
\text { non-cropland } \\
\text { Not registered in } \\
\text { California }\end{array}$ & $\begin{array}{l}\text { Weed control in seedling or established pasture or wildlife } \\
\text { plantings } \\
\text { Controls both broadleaf and annual grass weeds. }\end{array}$ \\
\hline MCPA & $1.0-4.0 \mathrm{pt}$ & $\begin{array}{l}\text { Pasture, } \\
\text { non-cropland }\end{array}$ & Weed control in established grass or grass/legume pastures \\
\hline $\begin{array}{l}\text { Paraquat } \\
\text { Gramoxone-Max }\end{array}$ & $0.8-1.5 \mathrm{pt}$ & $\begin{array}{l}\text { Pasture, } \\
\text { alfalfa; } \\
\text { non-cropland }\end{array}$ & $\begin{array}{l}\text { Weed control before or at planting } \\
\text { Grass sod suppression for interseeding legumes } \\
\text { Winter annual grass control prior to grass/legume green-up }\end{array}$ \\
\hline $\begin{array}{l}\text { Tebuthiuron } \\
\text { Spike 20P }\end{array}$ & $\begin{array}{l}0.37-0.75 \mathrm{oz} \\
\text { per } 100 \mathrm{sq} \mathrm{ft}\end{array}$ & $\begin{array}{l}\text { Pasture, } \\
\text { non-cropland }\end{array}$ & $\begin{array}{l}\text { Woody plant control } \\
\text { Only use for spot treating undesirable brush and woody } \\
\text { plants. }\end{array}$ \\
\hline $\begin{array}{l}\text { Triclopyr } \\
\text { Remedy Garlon }\end{array}$ & $0.5-1.5 \mathrm{qt}$ & $\begin{array}{l}\text { Pasture, } \\
\text { non-cropland }\end{array}$ & Weed and brush control in established grass pasture \\
\hline $\begin{array}{l}\text { Triclopyr + clopyralid } \\
\text { Redeem R\&P }\end{array}$ & $1.5-4.0 \mathrm{pt}$ & $\begin{array}{l}\text { Pasture, } \\
\text { non-cropland }\end{array}$ & $\begin{array}{l}\text { Weed control in established grass pasture } \\
\text { Controls several perennial weeds. }\end{array}$ \\
\hline
\end{tabular}

\section{Remarks and grazing restrictions}

Read label for product rates since 2,4-D has many different formulations.

Do not graze for 7 days or hay for 30 days following treatment.

Do not hay or graze for 30 days following treatment.

Safe on most seedling grass and legumes

No grazing restrictions

Provides good control of hoary cress, perennial pepperweed, and other members of the mustard family.

No grazing restrictions

Best treatment for yellow starthistle

Add dicamba to 2,4-D to improve control of biennial and perennial thistles.

Check label for grazing restriction.

Controls most emerged grass and broadleaf weeds.

Do not graze or hay for 30 days following treatment.

Do not hay for 7 days following treatment.

Selectively controls several annual grasses.

Poor control of thistles and most members of the sunflower family

Do not hay or graze for 7 days following treatment.

MCPA can injure legumes.

Do not hay or graze for 30 days following treatment.

Controls emerged seedling weeds.

Read label for grazing and hay restrictions.

Read label for grazing restrictions.

Do not hay for 7 days following treatment. 


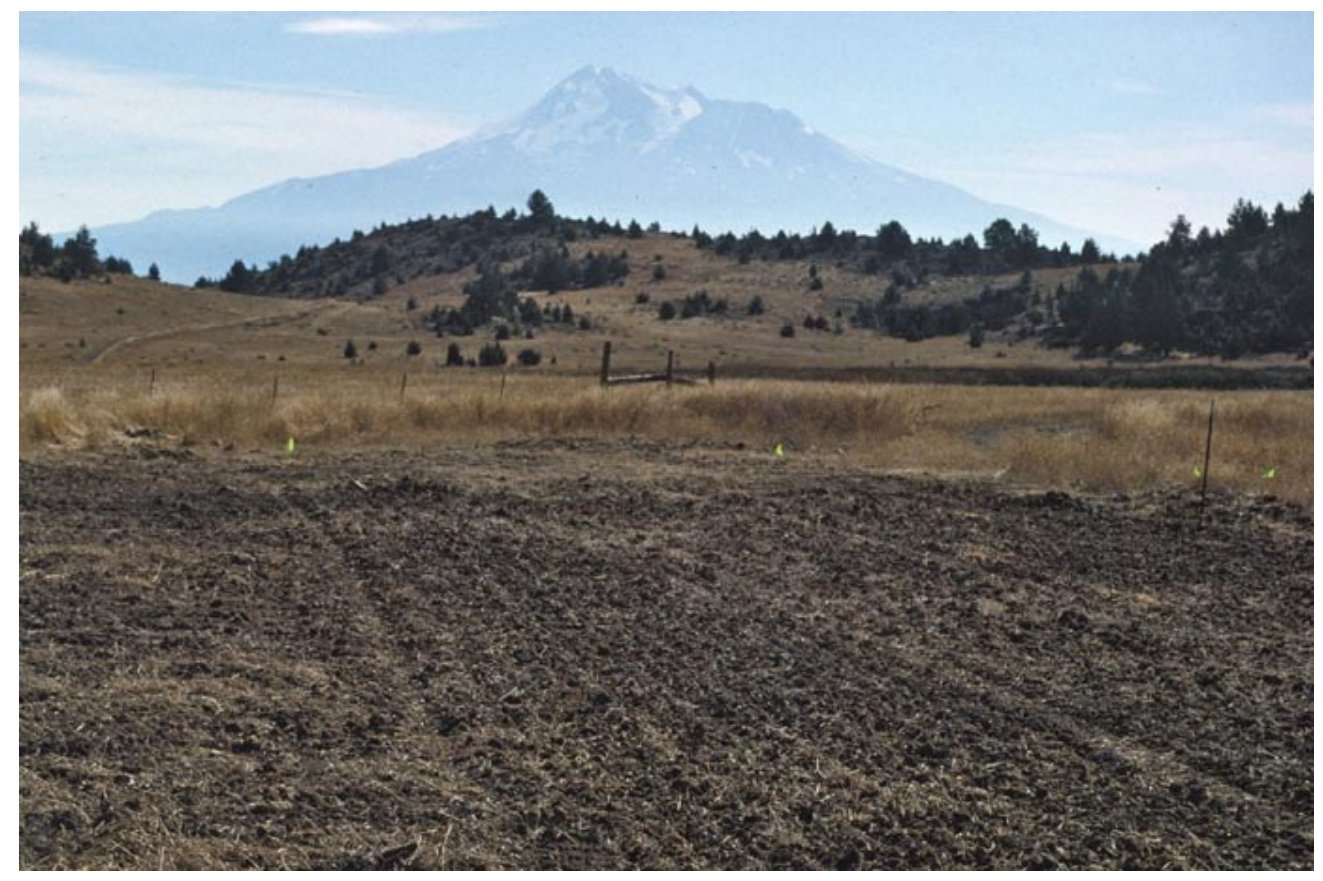

Re-seeding patchy dryland pasture following a controlled burn. Notice that the burn removed old grass and weed thatch, allowing good seed placement with a drill.

\section{Weed Control after Pasture Establishment}

A healthy, dense stand of perennial vegetation is the best prevention strategy against weeds. For this reason, promote the growth and vigor of desired species through proper grazing management (see Management after Seeding section). If pasture stands become patchy and depleted over time, re-seed desirable perennial grasses or forbs to thicken the stand. If weeds become established, determine the cause and treat the infestation as soon as possible to keep them from spreading.

Common causes for weed invasion include overgrazing, prolonged drought, poor stand establishment, and weed growth along the borders of adjacent fields. Seasonal grazing patterns also have a profound effect on weed encroachment (see Management after Planting section). In general, early spring grazing favors the growth of annual weeds, while summer or fall grazing generally does not. Livestock, field equipment, cars and trucks, all-terrain vehicles, and wildlife also move weeds from one location to another. To prevent these problems, do not overgraze pastures (especially those that are newly established), control weeds along field borders and non-crop areas, and clean vehicles, equipment, and livestock after they visit weed-infested areas.

Several techniques are available for controlling weeds in established pastures. Hand-pulling and digging are effective ways to control small, spotty weed infestations. Properly timed mowing can control some weeds or prevent the production of weed seed. In many cases, mowing annual and biennial weeds at bud or early flowering stage will prevent seed production and minimize the chances for regrowth. Controlled burning can be used to manage weeds. Grassland fires usually do not burn hot enough to kill weed seed on the ground, but burning does control some unwanted brush species and helps removes excessive weed thatch. Properly timed burns in early summer after the perennial grasses mature can effectively control some late-maturing annuals such as medusahead and yellow starthistle.

Several herbicides can provide effective control of weeds in established pastures (see Tables 4 and 5). In many cases, an herbicide can offer the most effective and least environmentally disruptive weed control option. Clopyralid (Transline), chlorsulfuron (Telar), 2,4-D, and dicamba (Banvel) all are herbicides that selectively kill broadleaf weeds and are safe to use on most grasses, making them very useful for control of broadleaf weeds in an established grass pasture. Glyphosate (Roundup) and paraquat (Gramoxone) are non-selective herbicides that kill most plants, so you should only use them for spot-treating or controlling weeds before you re-seed bare areas. You can also use Triclopyr (Remedy), tebuthiuron (Spike), and hexazinone (Velpar) to spot-treat brush and woody vegetation, but make sure to read the label since these products can have multi-year grazing and plant-back restrictions. In general, herbicides work best when applied in spring to small, actively growing annual and biennial weeds. 
Usually the best times to treat perennial weeds are in late spring when they are flowering or during the fall. For more information on individual herbicides, see Table 5 . Always read the product label before applying an herbicide. Most weed seeds persist for several years in the soil, so a single herbicide application provides effective long-term weed control. For this reason, always re-visit the treated site to monitor the herbicide's effectiveness and determine whether follow-up treatments are needed. If the pasture stand becomes depleted or patchy after herbicide treatment, re-seed it with desirable vegetation to prevent new weeds from taking over the bare spots.

\section{FERTILIZATION}

\section{Don Lancaster and Rob Wilson}

A soil analysis prior to planting can help you determine certain soil properties and nutrient levels important for establishing dryland pasture. An accurate understanding of your soil's $\mathrm{pH}$, texture, and salinity (elec-

Table 6. Desirable soil properties for dryland pasture

\begin{tabular}{|c|c|c|}
\hline Soil test & $\begin{array}{l}\text { Desired range for } \\
\text { soil test results }\end{array}$ & Comments \\
\hline pH & $\begin{array}{l}5.5 \text { to } 8.0 \text { (for most } \\
\text { grass species) }\end{array}$ & $\begin{array}{l}\text { Most legumes require a pH between } \\
6.3 \text { to } 8.0 \text {. }\end{array}$ \\
\hline $\begin{array}{l}\text { Electrical } \\
\text { conductivity (EC) }\end{array}$ & $<4.0$ to $6.0 \mathrm{dS} / \mathrm{m}$ & $\begin{array}{l}\text { If EC is higher than } 4 \mathrm{dS} / \mathrm{m} \text {, plant } \\
\text { salt-tolerant species. }\end{array}$ \\
\hline $\begin{array}{l}\text { Sodium adsorption } \\
\text { ratio (SAR) }\end{array}$ & $<13$ & $\begin{array}{l}\text { If SAR is higher than } 10 \text {, choose forage } \\
\text { species that are drought- and salt-tolerant. }\end{array}$ \\
\hline Sulfur & $>10 \mathrm{ppm}$ & $\begin{array}{l}\text { A plant tissue test more accurately estimates } \\
\text { sulfur availability and should be used after } \\
\text { grass establishment. }\end{array}$ \\
\hline
\end{tabular}
trical conductivity [EC] and sodium adsorption ratio [SAR]) will help you make the best choice of which plant species to seed (Table 6). A new pasture rarely requires fertilization during pasture establishment, but if you estimate some of the soil's nutrient levels based on a thorough soil test it will help you determine the site's yield potential and the possibility of phosphorus deficiency. After establishment you can determine nutrient levels through plant tissue tests.

\section{Correcting Nutrient Deficiencies}

\section{Nitrogen}

Seeding-time applications of nitrogen fertilizer generally are not recommended. Weedy annual grasses and forbs compete better and utilize nitrogen more efficiently than small perennial grass seedlings. After pasture establishment, nitrogen fertilizer can increase grass yield and vigor, but only apply nitrogen to a dense, healthy grass stand to make efficient use of the nutrient. In the intermountain region, growers cannot expect to see an economically beneficial response to applied nitrogen on sites with less than 20 inches of annual precipitation. On sites with more than 20 inches of annual precipitation, broadcast applications of ammonium sulfate (21-0-0-24S), urea (46-0-0), or nitrogenplus-phosphorus fertilizers (11-52-0 or 16-20-0-15S) can provide a cost-effective yield response. Fifty pounds of nitrogen per acre at the time of grass green-up in late winter (February-March) will usually provide the best yield response.

\section{Phosphorus}

A phosphorus deficiency can sometimes occur in intermountain region pastures, especially if legumes are among the species that are planted. Since phosphorus is an important nutrient for grass and forb seedling development, it is best to conduct a phosphorus soil test before planting. A soil test result below $5 \mathrm{ppm}$ would indicate that before seeding you should broadcast apply and shallowly incorporate a phosphorus fertilizer at 60 to 90 pounds of $\mathrm{P}_{2} \mathrm{O}_{5}$ per acre. If you plant with a seed drill that has a fertilizer box, apply phosphorus fertilizer with the seed so the phosphorus will concentrate around 
the germinating seeds where weeds are less likely to use it first. Phosphorus fertilizers with minimal nitrogen content, such as triple superphosphate (0-45-0) or 11-52-0, should be used for phosphorus fertilization at planting. After pasture establishment, you can broadcast nitrogen-plus-phosphorus fertilizers such as 16-20-0-15S and 11-52-0 onto the soil surface to provide phosphorus and a low rate of nitrogen.

\section{Sulfur}

Many soils in the intermountain region are inherently deficient in sulfur. If previous experience or soil tests indicate a possible sulfur deficiency, incorporate 200 to 300 pounds per acre (lb/ac) of elemental sulfur into the soil at seeding. This one application will provide 4 to 6 years of adequate sulfur nutrition to the new pasture plants. Visible symptoms of sulfur deficiency include stunting and yellow color, although these symptoms also commonly indicate nitrogen deficiency. If you suspect sulfur deficiency after pasture establishment, cut the top 4 to 6 inches off of leaves at early bloom and submit a plant tissue sample to a lab for analysis. If grass tissue results indicate a sulfur level of less than 0.10 to 0.15 percent, you may have a sulfur deficiency. Common solutions are broadcast applications of soluble sulfur fertilizers such as ammonium sulfate or gypsum.

\section{Potassium}

Soil potassium is rarely deficient in the intermountain region. If a soil test indicates a potassium level below 40 to $60 \mathrm{ppm}$ or a plant tissue sample indicates potassium below 1.5 percent, a potassium deficiency may exist. You can correct the deficiency by applying muriate of potash (0-0-60), usually the most economical potassium fertilizer.

\section{Micronutrients}

Micronutrients are hardly ever deficient in dryland pastures. Perennial grasses utilize and recycle nutrients very efficiently and they rarely develop micronutrient deficiencies. If you suspect a micronutrient problem in pasture forbs or legumes, collect plant tissue samples and have them analyzed by a testing lab. Two useful books, The Western Fertilizer Handbook and Intermountain Alfalfa Management, provide information on critical micronutrient ranges for alfalfa and legumes.

\section{MANAGEMENT AFTER PLANTING}

\section{Dan Drake and David Lile}

\section{Grazing Management of New Seedings}

The overriding characteristic common to newly established, dryland plant species is their low seedling vigor and slow growth and maturation. Typically, dryland perennial seedlings are so slow to get started that even several months after seeding their slim, vertical stalks are difficult to see. Since perennial seedlings mature slowly and are particularly susceptible to stress, a grower may not consider the stand to be "established" until it is 3 years old. Potential causes of pasture damage or loss may include lack of moisture and consumption by any number of animals, including cattle, deer, rabbits, ground squirrels, mice, and insects such as grasshoppers. Proper timing of cultural practices, seeding methods, and weed control help improve soil moisture conditions, but grazing must be light and controlled during pasture establishment to avoid excessive seedling losses.

Try not to allow grazing (plant consumption) in the year of establishment, at least until the seedlings have completed their growth for the first growing season. Timing 


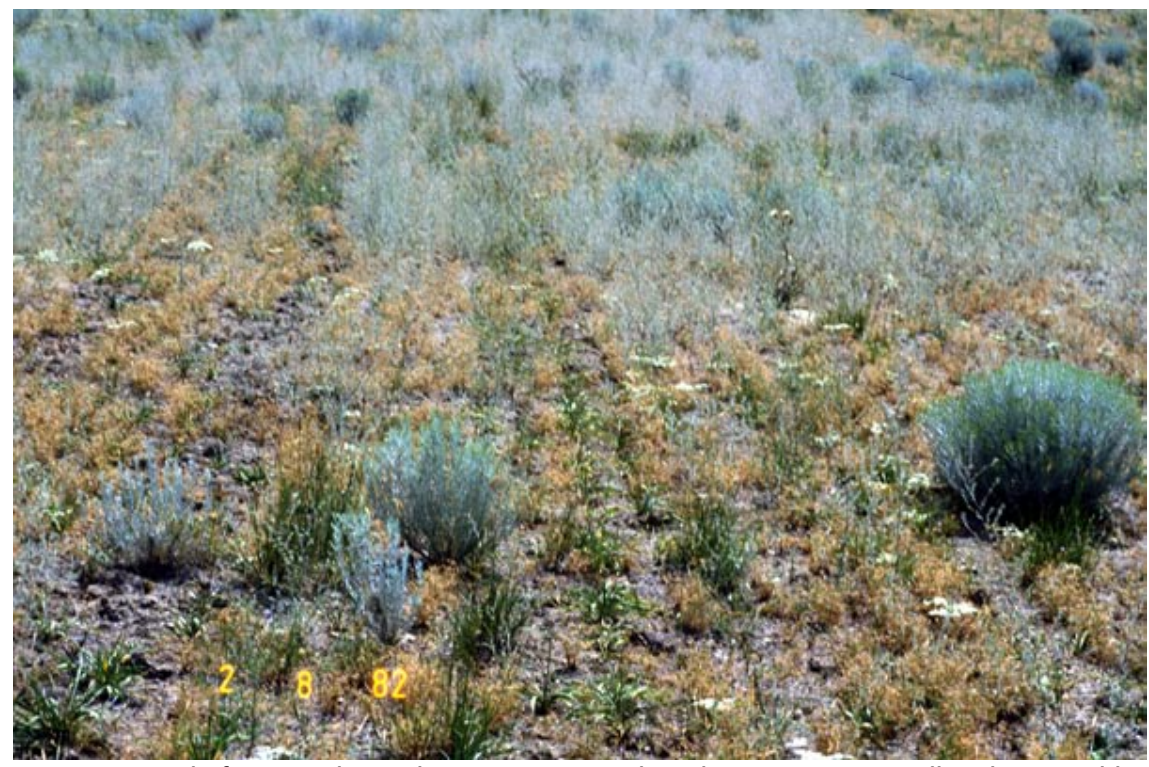

First-year stand of intermediate wheatgrass. Notice that plants are quite small and susceptible to stress even after a full season of growth.
Photo by Dan Drake. will vary depending on elevation and site conditions, but this usually means no grazing before July 1 . Under favorable growing conditions, the seeded plants will have developed numerous leaves and produced a seed head. After the plants produce a seedhead and go dormant (usually late in summer), livestock can graze them down to 3 to 4 inches in height. If growing conditions are poor and the plants do not produce a seedhead, do not allow grazing at all. Regardless of growing conditions, many people merely plan not to graze a newly established pasture in its first year, just to be on the safe side.

Proper grazing management (i.e., what type of livestock to graze, and how many, how often, and for how long to graze) is hard to determine during that first year. Often, the greatest benefit to the pasture from grazing is that grazing animals remove weeds such as annual mustards and grasses. Consider any grazing during the first year to be a prescribed clean-up operation rather than an extensive feeding on perennial seedlings. The key is to avoid grazing either too early in the summer, too close to the ground, or in muddy conditions. Grazing in late fall or winter should be avoided if muddy conditions exist, since the pasture will have developed very little sod by then to stabilize the soil and prevent soil compaction or erosion.

Although livestock grazing can be controlled during seedling establishment, it is often impossible to control grazing by wildlife. Small plantings usually are the most susceptible to wildlife damage since it only takes a few animals to completely defoliate a small stand. In areas with large numbers of deer, rabbits, ground squirrels, or elk, you can seed areas of five or more acres at a time to reduce the chance of a complete loss of stand from wildlife grazing, although some areas of your planting may still be severely damaged. Along with wildlife, insects such as grasshoppers, Mormon crickets, and black grass bugs can cause significant damage to new seedings. During a year with high insect populations, you may have to apply some sort of control. In most cases, insecticides provide the best control for insects feeding on new seedlings, since a large insect population can destroy a stand in a matter of a few days. You will have to choose the most appropriate insecticide to use based on the particular insect pest and local site conditions, so you will do best to consult an agricultural specialist in the area before you apply a treatment.

The second season after seeding, your management efforts should still focus on pasture stand establishment and you should continue to follow similar grazing guidelines to those you used the first year. Try to delay grazing until the plants have had the opportunity to complete their full growth for the season. Once drought conditions and cool temperatures have forced the plants into dormancy, graze them to a height of 3 to 4 inches and avoid grazing in muddy conditions. 


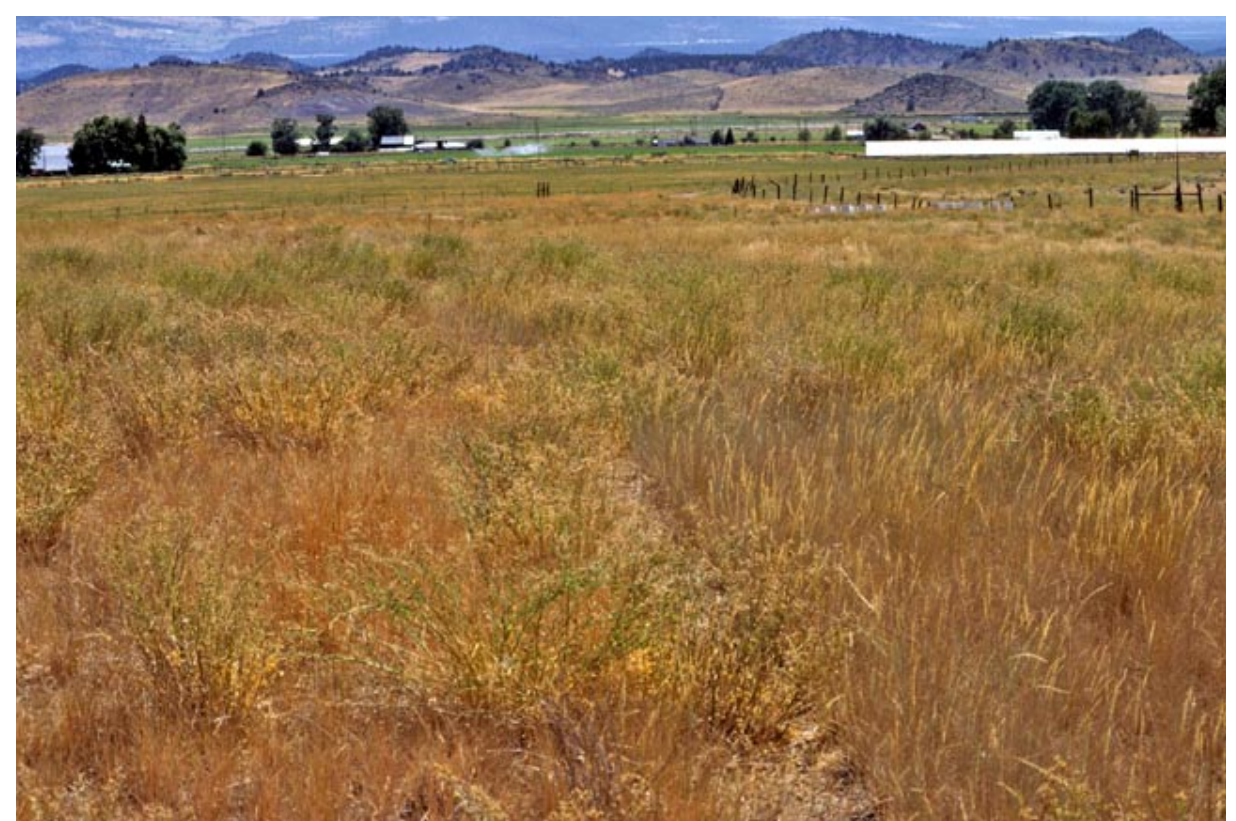

Third-year stand of intermediate wheatgrass. Notice that plants are well established and productive. Photo by Dan Drake.
If growing conditions are favorable during the first two years, plants generally are well established by the third spring and you can proceed to manage the field as an established perennial grass pasture. If the first two years are marked by drought conditions, allow a third year of restricted grazing. This timeline is most applicable to introduced species such as crested or intermediate wheatgrasses that have good seedling vigor and grazing tolerance. Native species that grow slowly and are sensitive to grazing may need three to five years to become completely established.

\section{Grazing Management of Established Dryland Forages}

Be cautious and conservative when you manage livestock grazing on dryland pasture, since desirable, dryland plants are quick to be degraded and slow to recover. Do not start a problem that may persist for years, just in order to get a little extra grazing in one year. Be especially careful when you graze livestock during drought cycles that persist beyond a single growing season. The combined stress of drought and heavy grazing will significantly diminish plant vigor. Under severe conditions, improper grazing can lead to the loss of desired plant species, which will then be replaced by weeds. Weeds make pasture rejuvenation difficult and often lead to permanent changes in vegetation.

Historical practice indicates that the best approach is to vary the season of use and

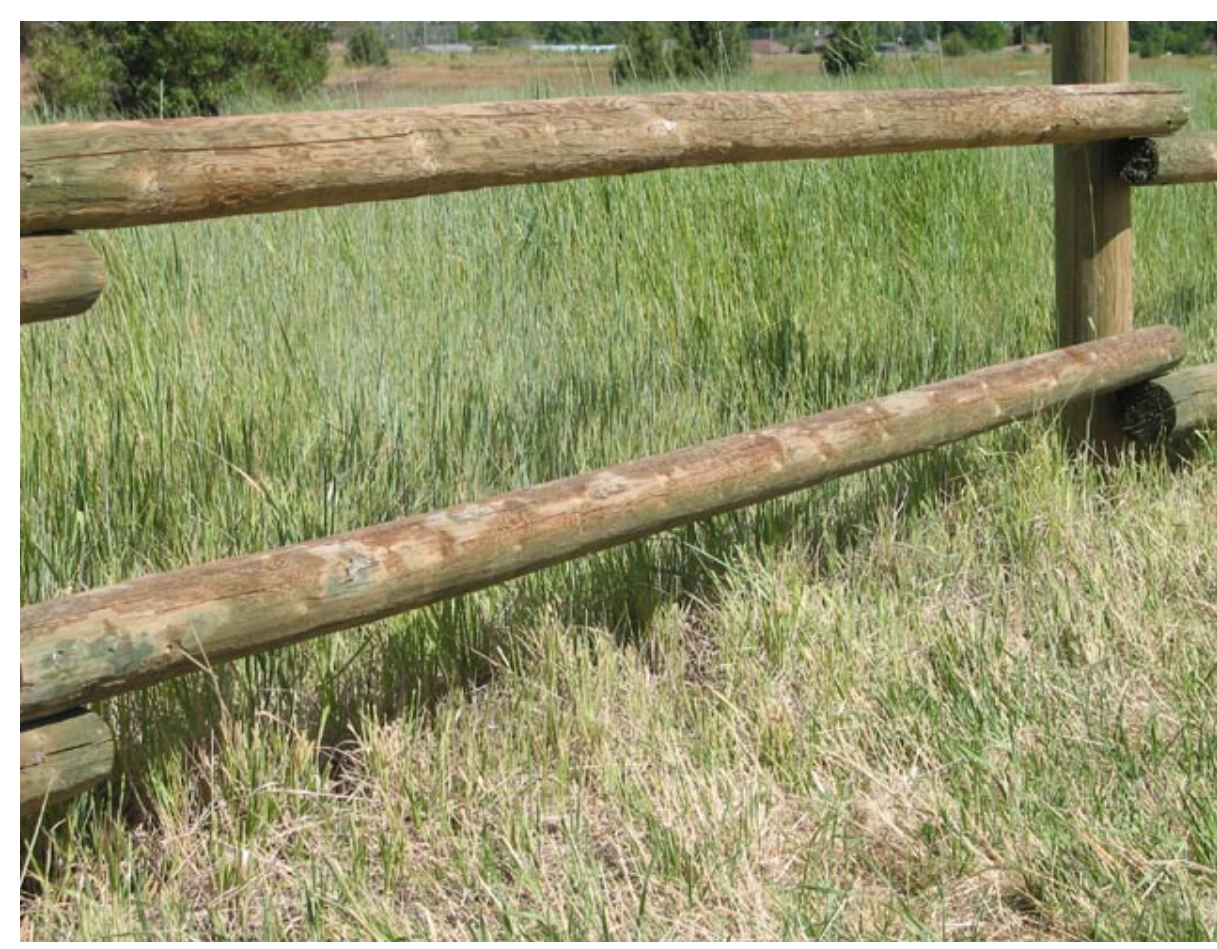

Proper summer grazing management (in front of the fence) compared to ungrazed area (behind the fence). Notice 3 to 4 inches of grass stubble were not grazed to promote regrowth. to leave half of the forage growth ungrazed. For example, forage used in the spring this year should be grazed later in the growing season next year. This provides a long period of uninterrupted growth during which the plants can replenish their root reserves. When grazing in late spring and early summer, leaving half of the current year's growth is a conservative practice that preserves the plants' energy reserves in their roots and stems. If grazing is delayed until late summer or fall, pastures can be grazed down to a 3- to 4-inch stubble height without causing harm.

In practice, these recommendations are best suited to producers who have enough pastures to permit a rotation that grazes some fields early one year and late the next year. 
But if you only have a single pasture to work with, it is best to defer grazing until early summer in order to prevent weed invasion and allow the plants to recover their energy reserves. If the area receives ample precipitation, a single-unit pasture can occasionally be grazed in early spring, but always make sure to leave half of the current year's growth and stop the grazing before soil moisture is depleted. When wheatgrass pastures are grazed in early summer, it may be possible to graze them again lightly in the fall or early winter. If you do allow fall or early winter grazing, begin after the onset of winter dormancy (October) and stop before the initiation of spring growth (January to March). Depending on what type of livestock are grazing, you may need to supplement their feed with hay in order to provide adequate nutrition during fall and winter grazing periods.

Early spring grazing usually is not appropriate for degraded ranges or areas that are susceptible to invasion by annual weeds. In field trials conducted on Siskiyou County pastures that had high annual weed pressure, early spring grazing resulted in a more extensive invasion of undesirable annuals than in pastures subjected to late spring or summer grazing (unpublished data). This research suggest that canopy removal in early spring allows greater exposure to sunlight and seed-to-soil contact to encourage the establishment of annual weeds that out-compete later maturing perennials. For this reason, it is probably best to avoid early spring grazing.

\title{
Non-grazing Management: Mowing and Fire
}

Even if you do not graze your pastures, you sometimes have to remove plant cover using non-grazing management practices to prevent insect and disease problems and fire hazard concerns. The decision whether to mow or burn depends on how you want the pasture to look as well as several site characteristics. If unmanaged, perennial grasses create large amounts of dry, dead grass (thatch), posing a fire hazard. You can leave some plant material intact to help prevent invasion by non-native annuals and weeds, but if you leave too much it can lead to insect and fire problems. When practical, try to mow and bale excess forage and so reduce the accumulation of thatch and accelerate its decomposition. The best time to mow is after perennial grasses produce seed. You may also want to use controlled burning to remove accumulated thatch. Burning is a risky endeavor, though, and must be coordinated with the local fire department or the California Department of Forestry and Fire Protection (CDF). The best time to burn is after completion of perennial grass growth, but the exact timing of the burn depends on permit restrictions as well as site characteristics and other vegetation growing on the site.

\section{ADDITIONAL TECHNICAL AND FINANCIAL ASSISTANCE}

\author{
Holly George and Alan Bower
}

\section{Technical Assistance}

Several organizations provide assistance to help landowners establish and manage dryland pastures. Here are the names of a few:

- University Cooperative Extension, agricultural and natural resource information, education, and research available through land-grant universities. You can find contact information for University of California Cooperative Extension county offices online: http://ucanr.org/ce.cfm 
- Natural Resources Conservation Service (NRCS), a division of the United States Department of Agriculture that assists private landowners with natural resource and agricultural concerns. Contact information for individual NRCS service centers in California is available online: http://offices.sc.egov.usda.gov/locator/app?state=ca

- Conservation Districts, commonly referred to as Soil and Water Conservation Districts or (in California) Resource Conservation Districts (RCDs).

Conservation districts are created on the local level (generally but not exclusively within county boundaries) to assist in local natural resource concerns. For an online listing of individual California RCD offices, visit:

http://www.carcd.org/wisp/countyframe.htm

\section{Financial Assistance}

The input costs of planting and maintaining dryland pasture land can prove to be a major barrier even for the best-intentioned land manager. Fortunately, the burden of such expenses does not necessarily have to be carried by a landowner/manager alone. Financial assistance is available at the federal and local levels.

The United States Department of Agriculture's Natural Resources Conservation Service (NRCS) offers a variety of programs and often provides cost sharing to landowners for several practices highlighted in this manual. However, in order to participate in NRCS programs, you have to contact your local NRCS office staff and create a plan that highlights the desired practices and outcomes.

The programs offered by the NRCS to help you successfully manage dryland pastures are summarized below.

- Environmental Quality Incentives Program (EQIP). The Environmental Quality Incentives Program promotes agricultural production and environmental quality as compatible goals. Through EQIP, farmers and ranchers receive financial and technical assistance to install or implement conservation management practices. EQIP program projects are planned to last for periods of 2 to 10 years.

- Wildlife Habitat Incentives Program (WHIP). The Wildlife Habitat Incentives Program encourages private landowners to create high-quality fish and wildlife habitats. NRCS offers technical and financial assistance to landowners and others to help them develop upland, wetland, riparian, and aquatic habitat. A typical project is designed for 5 to 10 years, but funds may be available for shortterm projects designed to meet emergency wildlife needs.

- Grassland Reserve Program (GRP). The Grassland Reserve Program is a voluntary program that helps landowners and operators restore and protect grasslands, including rangeland, pastureland, and certain other lands while at the same time maintaining the areas as grazing lands. This program offers a choice of several enrollment options: Permanent Easement, 30-year Easement, Rental Agreement, or Restoration Agreement. Cost-sharing rates for practices vary depending on the enrollment option. Contact your local NRCS office for further information (online at http://offices.sc.egov.usda.gov/locator/app).

- Conservation Reserve Program (CRP). The Conservation Reserve Program is a Farm Services Agency (FSA) program administered by the NRCS and is available to agricultural producers who manage croplands (including field margins) and marginal pasture lands. Producers enrolled in the CRP manage resources and vegetative cover in order to improve the quality of water, control soil erosion, and enhance wildlife habitat. In return, FSA provides rental payments (on a peracre basis), cost-share assistance, and up-front signing incentive payments (onetime payments upon enrolling the land into the CRP program). 
Funding may also be available through local Conservation Districts. Conservation Districts have been established throughout the country to help landowners and the federal government address natural resource concerns on the local level. In California, these districts are called Resource Conservation Districts (RCDs). Some districts offer financial grants and cost-share programs that are independent of the NRCS to assist landowners. It is important for you to contact your local RCD to find out if such funding is available.

Finally in some areas of Northern California, funds collected from commercial activities that take place on public lands (e.g., the sale of timber) are reapportioned to the counties where these funds were collected, the intent being to use these funds for natural resource improvement projects. As a result, local Resource Advisory Committees (RACs) are formed to evaluate and select projects to be eligible for such funds. To find out if there is a RAC in your area, contact your local United States Forest Service office or Bureau of Land Management office.

\section{USEFUL RESOURCES}

\section{Internet Sites}

- UC Davis Weed Research and Information Center http://wric.ucdavis.edu

- California Invasive Plant Council (Cal-IPC) http://www.caleppc.org

- Fire Effects Information System (FEIS) Invasive Plant Summaries http://www.fs.fed.us/database/feis

- USDA Plants Database http://plants.usda.gov

- The Nature Conservancy Invasive Species Management Summaries (ESA) http://tncweeds.ucdavis.edu/esadocs.html

\section{Books}

-Whitson, T. D., L. C. Burrill, S. A. Dewey, D. W. Cudney, B. E. Nelson, R. D. Lee, and R. Parker. 2002. Weeds of the west. Ninth edition. Newark, CA: Western Society of Weed Science. (also UC ANR Publication 3350)

- Sheley, R. L., and J. K. Petroff. 1999. Biology and management of noxious rangeland weeds. Corvallis: Oregon State University Press.

- Fischer, B. B, A. H. Lange, and J. McCaskill. 1992. Grower's weed identification handbook. Oakland: University of California, Division of Agriculture and Natural Resources. Publication 4030.

- Orloff, S. B., and H. L. Carlson. 1997. Intermountain alfalfa management. Oakland: University of California, Division of Agriculture and Natural Resources. Publication 3366.

- DiTomaso, J. M., and E. A. Healy. In press. Weeds of California and other western states. Oakland: University of California, Division of Agriculture and Natural Resources. Publication 3488.

- California Plant Health Association. 2002. Western fertilizer handbook. Ninth edition. Sacramento: California Plant Health Association. 


\section{FOR MORE INFORMATION}

You'll find related information in these titles and in other publications, slide sets, CD-ROMs, and videos from UC ANR:

Intermountain Alfalfa Management, Publication 3366

Weeds of the West, Publication 3350

To order or obtain printed ANR publications and other products, visit the ANR

Communication Services online catalog at http://anrcatalog.ucdavis.edu. You can also place orders by mail, phone, or FAX, or request a printed catalog of our products from:

University of California

Agriculture and Natural Resources

Communication Services

6701 San Pablo Avenue, 2nd Floor

Oakland, California 94608-1239

Telephone: (800) 994-8849 or (510) 642-2431

FAX: (510) 643-5470

E-mail inquiries: danrcs@ucdavis.edu

An electronic version of this publication is available on the ANR Communication Services Web site at http://anrcatalog.ucdavis.edu.

Publication 8163

This publication has been anonymously peer reviewed for technical accuracy by University of California scientists and other qualified professionals. This review process was managed by the ANR Associate Editor for Agronomy and Range Sciences.

C 2006 by the Regents of the University of California Division of Agriculture and Natural Resources.

All rights reserved.

The University of California prohibits discrimination or harassment of any person on the basis of race, color, national origin, religion, sex, gender identity, pregnancy (including childbirth, and medical conditions related to pregnancy or childbirth), physical or mental disability, medical condition (cancer-related or genetic characteristics), ancestry, marital status, age, sexual orientation, citizenship, or status as a covered veteran (covered veterans are special disabled veterans, recently separated veterans, Vietnam era veterans, or any other veterans who served on active duty during a war or in a campaign or expedition for which a campaign badge has been authorized) in any of its programs or activities.

University policy is intended to be consistent with the provisions of applicable State and Federal laws.

Inquiries regarding the University's nondiscrimination policies may be directed to the Affirmative Action/Staff Personnel Services Director, University of California, Agriculture and Natural Resources, 1111 Franklin Street, 6 ${ }^{\text {th }}$ Floor, Oakland, CA 94607, (510) 987-0096. For information about obtaining this publication, call (800) 994-8849. For downloading information, call (530)2974445.

pr-2/06-WJC/CR

ISBN 978-1-60107-332-7 